\title{
Calea (Asteraceae, Neurolaeneae) no estado de Goiás, Brasil
}

\author{
Calea (Asteraceae, Neurolaeneae) in Goiás state, Brazil
}

Gustavo Henique Lima da Silva ${ }^{1,2}$ \& Aristônio M. Teles ${ }^{1}$

\begin{abstract}
Resumo
Calea é um gênero com distribuição neotropical com cerca de 120 espécies, sendo o maior em número de espécies entre os seis gêneros da tribo Neurolaeneae (Asteraceae). No Brasil ocorrem 83 espécies das quais 46 são endêmicas do país. As regiões do Brasil com maior riqueza de espécies são Sudeste (52 spp.) e Centro-Oeste (40 spp.). O estado de Goiás localiza-se no Planalto Central Brasileiro com uma área de 340.111 $\mathrm{km}^{2}$ e é coberto principalmente por fitofisionomias do bioma Cerrado. Para a realização do trabalho foram realizadas coletas botânicas em vários pontos de Goiás durante o período de maio de 2014 à novembro de 2015. Foram examinados materiais de diversos herbários do Brasil e materiais oriundos de coletas próprias. Aqui são reportadas 26 espécies e um complexo de espécies de Calea para o estado de Goiás. É apresentada uma chave de identificação para as espécies ocorrentes no estado, além de descrições, ilustrações, comentários taxonômicos, distribuição geográfica, período de floração e frutificação, bem como material examinado.

Palavras-chave: Cerrado, Compositae, Heliantheae sensu lato.

Abstract

Calea is a Neotropical genus with 120 species. It is the largest one in number of species among the six genera of the tribe Neurolaeneae (Asteraceae). In Brazil occur 83 species of Calea, these total 46 are endemic of the country. The Brazilian region with more species is the Southeast (52 spp.), and Central-West (40 spp.). The state of Goiás is located in the Brazilian Central Plateau and has an area of approximately $340.111 \mathrm{~km}^{2}$ covered mainly by phytophysiognomies of the Cerrado biome. To perform this work were realized botanical collections in several points of Goiás state from May 2014 to November 2015. We examined materials of several Brazilian herbaria and materials from own collections. Herein are reported 26 species and a complex of species of Calea for the Goiás state. It is presented an identification key, descriptions, illustration, taxonomic comments, phenology, distribution, and examined material.
\end{abstract}

Key words: Brazilian savanna, Compositae, Heliantheae sensu lato.

\section{Introdução}

A família Asteraceae (Compositae) é a segunda maior entre as Angiospermas possuindo entre 1600-1700 gêneros e aproximadamente 24.000 espécies agrupadas em 44 tribos, divididas em 13 subfamílias e com distribuição cosmopolita (Funk et al. 2009; Panero et al. 2014).

O clado conhecido como Aliança Heliantheae (Heliantheae Alliance) é formado por 13 tribos de Asteraceae (Panero 2007a) e inclui cerca de 5500 espécies, algo entre $20 \%$ e $25 \%$ de todas as espécies da família. As espécices deste clado estão distribuidas especialmente pelo Novo Mundo e se caracterizam por apresentar brácteas involucrais 1-3-seriadas; anteras geralmente enegrecidas, ecaudadas e ecalcaradas; estiletes frequentemente recobertos por tricomas acima da divisão dos ramos do estilete que são recurvados na maturidade; e a maioria dos táxons possui uma camada de fitomelanina na cipsela (Baldwin 2009).

Neurolaeneae Rydb. é uma das tribos da Aliança Heliantheae, é uma tribo de distribuição neotropical e é representada por três subtribos (Enydrinae H.Rob., Heptanthinae H.Rob. e Neurolaeninae Stuessy, B.L.Turner \& A.M.Powell), cinco gêneros (Calea L., Enydra Lour., Heptanthus

\footnotetext{
${ }^{1}$ Universidade Federal de Goiás, Inst. Ciências Biológicas, Dep. Botânica, Câmpus Samambaia, Av. Esperança s/n, Vila Itatiaia, 74690-900, Goiânia, GO, Brasil.

${ }^{2}$ Autor para correspondência: gustavo.silva.bio@gmail.com
} 
Griseb., Neurolaena R.Br. e Staurochlamys Baker) e aproximadamente 153 espécies (Panero 2007b). Segundo BFG (2015), no Brasil Neurolaeneae está representada por duas subtribos (Enydrinae e Neurolaneinae), três gêneros (Calea, Enydra e Staurochlamys) e 85 espécies.

Calea é um gênero neotropical (Pruski \& Urbatsch 1988) e compreende aproximadamente 120 espécies (Panero 2007b; Baldwin 2009) agrupadas, segundo Pruski (1998), em cinco seções: Calea sect. Calea, C. sect. Haplocalea (Less.) Pruski, C. sect. Meyeria (DC.) Benth. \& Hook.f., $C$. sect. Monathocalea (Less.) Pruski e $C$. sect. Lemmatium (DC) Benth. \& Hook.f. No Brasil estão representadas todas essas seções com 83 espécies encontradas principalmente nas regiões Sudeste e Centro-Oeste, geralmente em formações savânicas e campestres (BFG 2015; Silva et al. 2016). Goiás é o segundo estado mais rico em número de espécies do gênero, sendo aqui tratadas 26, além de um complexo de espécies cujas delimitações morfológicas e taxonomia ainda precisam ser esclarecidas, ficando atrás apenas de Minas Gerais para onde são reportadas 48 espécies (BFG 2015).

$\mathrm{O}$ gênero Calea pode ser reconhecido especialmente pelo pápus de páleas livres ou muito raramente coroniforme; brácteas involucrais escariosas com nervuras conspicuamente marcadas; flores do raio, quando presentes, pistiladas; flores do disco com ductos resiníferos visíveis nas bordas das lacínias da corola e anteras amareladas tornando-se amarronzadas na maturidade ou em material seco.

O objetivo do presente trabalho é apresentar o tratamento taxonômico para as espécies de Calea ocorrentes no estado de Goiás, com a apresentação de chave de identificação para as espécies, ilustrações, descrições, comentários taxonômicos, distribuição geográfica, hábitat, período de floração e frutificação, além de material selecionado.

\section{Material e Métodos}

O estado de Goiás está localizado na região Centro-Oeste do Brasil e faz divisa com os estados da Bahia, Mato Grosso, Mato Grosso do Sul, Minas Gerais e Tocantins, além do Distrito Federal e possui uma área de aproximadamente $340.111 \mathrm{~km}^{2}$ (IBGE 2014). O estado está situado no Planalto Central Brasileiro com clima Aw de Köppen cobrindo cerca de $94 \%$ da área do estado com pequenas áreas de clima Am, Cwa, e Cwb de Köppen. A temperatura média anual é de $20^{\circ} \mathrm{C}$ e a precipitação anual varia de 1.600 a $1.900 \mathrm{~mm}$ (Alvares et al. 2014).
O material examinado foi oriundo de coletas próprias provenientes de 19 expedições realizadas entre maio de 2014 e novembro de 2015, tendo como áreas de coleta no estado de Goiás a Serra de Caldas (Caldas Novas), a Serra dos Pireneus (Pirenópolis), a Serra Dourada (Mossâmedes), a Chapada dos Veadeiros (Alto Paraíso de Goiás) e o Parque Nacional das Emas (Mineiros), além de coletas nos municípios de Colinas do Sul, Niquelândia, Baliza e Aragarças. Durante estas expedições foram coletadas 12 das 27 espécies aqui tratadas. Todo material coletado encontra-se depositado no herbário da Universidade Federal de Goiás (herbário UFG). Complementando o material coletado em campo também foi analisado o material referente a Goiás depositado nos herbários: ALCB, BHCB, CEN, CGMS, ESA, HEPH, HJ, HUEFS, HUEG, HUFU, IBGE, MBM, RB, UB, UFG, UFMT (acrônimos segundo Thiers continuously updated).

Todo material foi identificado ou teve a sua identificação revista através do uso de bibliografias específicas (e.g., Baker 1884; Barroso 1975; Robinson 1975, 1979; Urbatsch et al. 1986; Pruski \& Urbatsch 1987, 1988; Pruski 1998, 2005; Roque \& Carvalho 2011), por comparação com exemplares de herbário identificados por especialistas e por comparação com imagens de espécimes-tipo disponíveis na internet.

A descrição do gênero é uma compilação das descrições encontradas nas literaturas taxonômicas específicas (e.g., Baker 1884; Bremer 1994; Panero 2007b; Roque \& Carvalho 2011), complementada com a variação morfológica encontrada nas espécies examinadas.

As descrições das espécies foram feitas com base em material herborizado e com o auxílio de estereomicroscópio. A morfologia das estruturas reprodutivas e vegetativas foi caracterizada com base em Roque \& Bautista (2008), Gonçalves \& Lorenzi (2011), e as folhas com base em Ash et al. (1999).

A abreviação dos nomes dos protólogos está de acordo com BPH on line (2017) e o nome dos autores dos táxons estão baseados no IPNI (2017).

As informações sobre a distribuição geográfica foram baseadas a partir de coletas próprias, de informações contidas nas etiquetas das exsicatas examinadas e da literatura utilizada para identificação dos táxons. O período de floração e frutificação foi atribuído a partir das informações contidas nas etiquetas das exsicatas e através das observações de campo e dizem respeito aos materiais provenientes de Goiás. 


\section{Resultados e Discussão}

1. Calea L., Sp. Pl., ed. 2. 2: 1179. 1763.

Ervas, subarbustos eretos ou apoiantes, arbustos, ocasionalmente trepadeiras, lianas ou árvores; sistema subterrâneo às vezes desenvolvido na forma de xilopódio ou raízes tuberosas. Folhas simples, opostas ou verticiladas, às vezes as superiores alternas, raro todas alternas; lâmina linear, oblonga, elíptica, oval, oboval, lanceolada, rômbica, deltoide; sésseis ou pecioladas. Capítulos solitários ou capitulescências terminais ou axilares, radiados, heterógamos ou discoides, homógamos. Invólucro cilíndrico, obcônico ou campanulado; brácteas involucrais $2-8$-seriadas, as mais internas escariosas com nervuras conspicuamente marcadas, subiguais ou as externas menores, podendo ser dimorficas. Eixo da inflorescência plano, convexo ou cônico, usualmente paleáceo ou raro epaleáceo. Flores do raio, quando presentes, pistiladas, corola liguliforme amarela ou raro esbranquiçada, lâmina com ápice inteiro a 4-lobulado, patente; estiletes com ápice dos ramos obtuso, glabro. Flores do disco andróginas, corola tubulosa amarela, menos comumente brancas ou púrpura, 5-lacíniada; anteras com apêndice do conectivo agudo, base curtamente sagitada, amarelas a acastanhadas; ramos do estilete, ápice truncado, penicelado. Cipselas obcônicas ou prismáticas, 4-5-angulares, enegrecidas ou amarronzadas, seríceas, pubescentes, glabras, glabrescentes ou raro glandulares; pápus paleáceo ou raramente coroniforme, páleas livres (raramente conadas), desiguais ou subiguais, ápice e margem erosas, mais curtas ou com o mesmo comprimento da corola das flores do disco.

Aqui apresentamos para o estado de Goiás 26 espécies e um complexo de espécies ainda mal delimitadas (grupo Calea teucriifolia) de Calea. Segundo BFG (2015), C. anomala Hassl., C. kirkbridei H.Rob. e C. purpurea G.M.Barroso ocorrem em Goiás. Porém, constatou-se que os espécimes de C. anomala e C. kirkbridei reportados para a região na verdade se tratavam de exemplares de $C$. polycephala (Baker) H.Rob. e Aspilia pseudocalea G.Silva \& A.Teles (Silva $\&$ Teles 2017), respectivamente. Deste modo, $C$. anomala e $C$. kirkbridei são espécies que ocorrem no estado de Minas Gerais, sendo esta última aqui considerada como endêmica de Minas Gerais. Já os espécimes de C. purpurea (C.A. Miranda 175 e R.P. Orlandi 89) que evidenciam a ocorrência da espécie no estado de Goiás, tratam-se na verdade de exemplares coletados no estado de Tocantins, porém, antes da separação entre os dois referidos estados.

É apresentado um novo registro de Calea tocantina Pruski para Goiás. Além disso, foi constatado que $C$. chapadensis, $C$. robinsoniana e $C$. sickii são de distribuição restrita à região Centro-Oeste do Brasil, enquanto $C$. diffusa, $C$. irwinii, C. nervosa e C. aldamoides são endêmicas de Goiás.

\section{Chave de identificação das espécies de Calea ocorrentes no estado de Goiás}

1. Folhas verticiladas.

2. Capítulos discoides.

3. Lâmina foliar com face abaxial tomentosa, margem crenada a crenulada; eixo da inflorescência cônico; páleas oblongas 4. Calea chapadensis

3'. Lâmina foliar escabra em ambas as faces, margem serreada; eixo da inflorescência convexo; páleas obovais 22. Calea reticulata

2'. Capítulos radiados.

4. Invólucro 5-seriado; lâmina da flor do raio 13-18 mm compr.; páleas do pápus 1,6-2,7 $\mathrm{mm}$ compr., oblongas 20. Calea quadrifolia

4'. Invólucro 2-seriado; lâmina da flor do raio 4,5-5 mm compr.; páleas do pápus 4,4-6,7 mm compr., linear-lanceoladas 16. Calea mediterranea

1'. Folhas alternas, opostas ou opostas com gemas axilares desenvolvidas (falsamente verticiladas).

5. Capítulescência corimbiforme, dicasiforme, corimboso-dicasiforme, umbeliforme, ou dicásioumbeliforme.

6. Capítulos discoides.

7. Brácteas involucrais dimórficas, ou seja, 1 série externa com 2 ou $4-5$ brácteas involucrais foliáceas e 2 ou 3 séries internas com brácteas involucrais escariosas. 
8. Lâmina foliar pubescente a tomentosa em ambas as faces; eixo da inflorescência epaleáceo . 23. Calea robinsoniana

8'. Lâmina foliar glabra em ambas as faces; eixo da inflorescência paleáceo.

9. Margem foliar inteira; capitulescência corimboso-dicasiforme; 2 brácteas involucrais foliáceas 13. Calea irwinii

9'. Margem foliar crenada; capitulescência dicásio-umbeliforme; 4-5 brácteas involucrais foliáceas

15. Calea lutea

7'. Brácteas involucrais monomórficas, ou seja, todas escariosas.

10. Cipselas glabras; pápus $0,3-0,5 \mathrm{~mm}$ compr., páleas ovais livres.

11. Pecíolos 6-15 mm compr.; lâmina foliar com base obtusa; invólucro 4-seriado 19. Calea polycephala

11’. Pecíolos 1-4 mm compr.; lâmina foliar com base aguda; invólucro 3-seriado.

12. Pedúnculos glabros; invólucro cilíndrico; páleas do eixo da inflorescência planas; corolas com lacínios amarelos 6. Calea diffusa

12'. Pedúnculos puberulentos; invólucro campanulado; páleas do eixo da inflorescência conduplicadas; corolas com lacínios purpúreos 26. Calea tocantina

10'. Cipselas velutinas ou glanduloso-velutinas; pápus 1,7-5 mm compr., páleas lineares ou lanceoladas livres ou pápus coroniforme.

13. Capitulescência umbeliforme, ou dicásio-umbeliforme.

14. Lâmina foliar com face abaxial velutina; pedúnculos velutinos; comprimento da cipsela (1,8-2 mm compr.) menor que o do pápus (3,7-4,6 $\mathrm{mm}$ compr.)

14. Calea lantanoides

14'. Lâmina foliar com face abaxial glabra; pedúnculos glabros; comprimento da cipsela (3,3-3,7 mm compr.) maior que o do pápus (1,9-2,3 mm compr.)

7. Calea divergens

13'. Capitulescência corimboso-dicasiforme.

15. Pedúnculos velutinos; invólucro cilíndrico; 4-6 flores por capítulo; pápus de páleas lineares livres 9. Calea fruticosa

15'. Pedúnculos escabros; invólucro obcônico; 12-22 flores por capítulo; pápus coroniforme 24. Calea sickii

6'. Capítulos radiados.

16. Brácteas involucrais monomórficas, ou seja, todas escariosas.

17. Ervas eretas ou decumbentes, lâmina foliar glabra em ambas as faces; invólucro cilíndrico; 1-2 flores do raio 11. Calea hymenolepis

17'. Subarbustos eretos, lâmina foliar escabra em ambas as faces ou escabra na face adaxial e pubescente na face abaxial; invólucro campanulado; 5-11 flores do raio.

18. Folhas pecioladas, lâmina elíptica a oblonga, escabra na face adaxial e pubescente na face abaxial; páleas do eixo da inflorescência planas 3. Calea candolleana

18'. Folhas sésseis, lâmina linear a oblanceolada, escabras em ambas as faces; páleas do eixo da inflorescência conduplicadas.

19. Venação foliar acródroma suprabasal; brácteas involucrais escabras, ápice enegrecido; páleas do eixo da inflorescência linear-lanceoladas; corola das flores do disco glabras 8. Calea elongata

19’. Venação foliar semicraspedódroma; brácteas involucrais glabras, ápice esverdeado; páleas do eixo da inflorescência oblanceoladas; corola das flores do disco com tubo glanduloso 10. Calea gardneriana

16'. Brácteas involucrais dimórficas, ou seja, 1-2 séries externas com brácteas involucrais foliáceas e 2-4 séries internas com brácteas involucrais escariosas.

20. Lâmina foliar linear, estrigosa em ambas as faces 21. Calea ramosissima

20'. Lâmina foliar oval, lanceolada, oblanceolada ou rômbica, escabra, hirsuta, pubescente ou tomentosa em ambas as faces.

21. Invólucro 0,7-1 cm compr.; ápice das flores do raio 3-lobulado; flores do disco 8-35.

22. Lâmina foliar lanceolada, base obtusa; páleas do eixo da inflorescência planas e lineares 12. Calea hypericifolia 
22'. Lâmina foliar oblanceolada, oval ou rômbica, base aguda; páleas do eixo da inflorescência conduplicadas e oblongas ..... 25. Grupo Calea teucriifolia

21'. Invólucro 1,4-1,9 cm compr.; ápice das flores do raio 4-lobulado; flores do disco 40-81.

23. Folhas pecioladas, lâmina foliar hirsuta; brácteas involucrais foliáceas lanceoladas, 18-50 mm compr.

23. Calea nervosa

23'. Folhas sésseis, lâmina foliar velutina a escabra; brácteas involucrais foliáceas ovais a orbiculares, 4,2-9,6 mm compr. 27. Calea verticillata

5'. Capítulos solitários.

24. Brácteas involucrais dimórficas, ou seja, com 1-2 séries de brácteas involucrais foliáceas e 2-3 séries internas de brácteas involucrais escariosas.

25. Lâmina foliar linear a linear-elíptica ou lanceolada, glabra, pubescente ou hirsuta; brácteas involucrais foliáceas, lanceoladas.

26. Folhas sésseis, lâmina foliar linear a linear-elíptica, $0,2-0,5 \mathrm{~cm}$ larg., glabra a pubescente; ápice das flores do raio 3-lobulado 1. Calea abbreviata

26’. Folhas pecioladas, lâmina foliar lanceolada, $1-2,8 \mathrm{~cm}$ larg., hirsuta; ápice das flores do raio 4-lobulado

2. Calea aldamoides

25'. Lâmina foliar oboval, velutina; brácteas involucrais foliáceas, ovais a orbiculares

5. Calea cuneifolia

24'. Brácteas involucrais monomórficas, ou seja, todas as brácteas involucrais escariosas

17. Calea multiplinervia

1. Calea abbreviata Pruski \& Urbatsch, Brittonia 40: 348. 1988.

Iconografia: Pruski \& Urbatsch (1988: 349, Fig. 4)

Subarbustos eretos, $13-35 \mathrm{~cm}$ alt. Folhas opostas, sésseis; lâmina linear a linear-elíptica, $0,9-5 \times 0,2-0,5 \mathrm{~cm}$, venação acródroma basal, ápice agudo, base aguda, margem inteira, glabras a pubescentes. Capítulos solitários, radiados; pedúnculos 7,5-28,5 cm compr., glabros a pubescentes. Invólucro campanulado, dimórfico, $0,7-0,9 \times 0,6-1 \mathrm{~cm}, 3$-seriado; 1 série externa de 3 brácteas involucrais foliáceas, lanceoladas, $0,7-1 \times 0,3-0,4 \mathrm{~cm}$, ápice agudo, margem inteira, glabras; 2 séries internas de brácteas involucrais escariosas, elípticas, $0,8-1,2 \times 0,4-0,5 \mathrm{~cm}$, ápice obtuso, glabras. Eixo da inflorescência convexo; páleas planas, lineares, 6,2-7,7 $\mathrm{mm}$ compr., ápice agudo. Flores do raio 6-7, corola amarela, tubo 2-3,8 mm compr., lâmina $0,9-1,3 \times 0,3-0,6$ $\mathrm{mm}$, ápice 3-lobulado; estilete 3,5-4 $\mathrm{mm}$ compr., ramos do estilete $c a .1 \mathrm{~mm}$ compr. Flores do disco 24-30, corola amarela, 4,7-6,1 mm compr., glabra, tubo 1,6-2,2 mm compr., limbo 1,5-2 mm compr., lacínios 1,3-1,7 mm compr.; anteras 2,4 mm compr.; estilete 4,4-5 mm compr., ramos do estilete $0,7-1 \mathrm{~mm}$ compr. Cipselas 4-angulosas, 4,6-5 mm compr., glabras; pápus de páleas livres, estreito-lanceoladas, 1-2,1 mm compr.

Material selecionado: BRASIL. GOIÁS: Alto Paraíso de Goiás, GO-118 de Alto Paraíso de Goiás a Teresina de Goiás, 15,4 km N de Alto Paraíso, 1400'55”S, 47 31 '35”'W, 11.VI.2011, J. Bringel \& H.J.C. Moreira 822 (CEN, UB).

Distribuição, hábitat e fenologia: Goiás e Minas Gerais (BFG 2015). No estado de Goiás ocorre em áreas de campo limpo, campo úmido, campo rupestre e cerrado rupestre entre elevações de 1.125 a $1.460 \mathrm{~m}$, da Chapada dos Veadeiros. Fértil em fevereiro, junho, e de setembro a novembro.

Calea abbreviata é reconhecida por seu porte subarbustivo, com folhas lineares a linear-elipticas, sésseis, glabras a pubescentes, longos pedúnculos (7,5-28,5 cm compr.) com capítulos solitários. A espécie é morfologicamente semelhante à $C$. multiplinervia, porém diferencia-se desta pelas folhas glabras com margem inteira (vs. hirsutas com margem serreada em C. multiplinervia) e pápus com 1-2,1 mm compr. (vs. pápus com 5,5-6 $\mathrm{mm}$ compr.). Além disso, C. abbreviata apresenta invólucro com brácteas foliáceas o que não ocorre em C. multiplinervia. A espécie é considerada Criticamente em Perigo (Nakajima et al. 2013).

2. Calea aldamoides G.Silva, Bringel \& A.Teles, Phytotaxa 265(3): 279. 2016.

Iconografia: Silva et al. (2016: 281, 282, Figs. 1 e 2)

Subarbustos eretos, $55-82 \mathrm{~cm}$ alt. Folhas opostas, pecíolos 4-9 mm compr.; lâmina lanceolada, $5,2-11,5 \times 1-2,8 \mathrm{~cm}$, venação acródroma suprabasal, ápice agudo, base aguda a 
decorrente, margem inteira a denticulada, hirsuta em ambas as faces. Capitulos solitários, radiados; pedúnculos 25-36 cm compr., esparso-hirsutos. Invólucro campanulado, dimórfico, 1,2-1,5 × 1,2-1,5 cm, 4-seriado; 2 séries externas de 6 brácteas involucrais foliáceas, lanceoladas, 0,8-2 $\times 0,5-0,6 \mathrm{~mm}$, ápice agudo, margem serreada, escabras; 2 séries internas de brácteas involucrais escariosas, oblongas, $0,7-1,4 \times 0,3-7 \mathrm{~cm}$, ápice obtuso. Eixo da inflorescência convexo, paleáceo; páleas conduplicadas, lineares, $6,5-8,5 \mathrm{~mm}$ compr., ápice agudo. Flores do raio 11-15, corola amarela, tubo ca. 3,8 mm compr., lâmina $13 \times 4-5 \mathrm{~mm}$, ápice 4-lobulado; estilete $c a .5 \mathrm{~mm}$ compr., ramos do estilete $c a$. 1,7 mm compr. Flores do disco 45-67, corola amarela, 6,3-7 $\mathrm{mm}$ compr., glabra, tubo $c a$. $2 \mathrm{~mm}$ compr., limbo ca. $3 \mathrm{~mm}$ compr., lacínios 1,3-2 mm compr.; anteras $c a$. $3 \mathrm{~mm}$ compr., estilete ca. $6,4 \mathrm{~mm}$ compr., ramos do estilete $c a .1,8 \mathrm{~mm}$ compr. Cipselas 4-angulosas, 3,9-4,2 mm compr., glabras com tricomas apenas nos angulos; pápus de páleas livres, estreito lanceoladas, ca. $2 \mathrm{~mm}$ compr. Material examinado: BRASIL. GOIÁS: Cavalcante, estrada para a Estação Ecológica Córrego Branco, 133429"S, 4743'46”'W, 918 m, 1.II.2015, J. Bringel 1188 et al. (Isótipo CEN, Holótipo UFG).

Distribuição, hábitat e fenologia: Espécie conhecida até o momento apenas pelo material tipo coletado no município de Cavalcante no estado de Goiás. Cresce em cerrado ralo em cambissolo com relevo inclinado. Coletada fértil no mês de fevereiro.

Calea aldamoides possui morfologia semelhante a C. multiplinervia por se tratar de um subarbusto simples, com folhas opostas e capítulos radiados e solitários. Porém, diferencia-se desta espécie por apresentar nervação acródroma suprabasal (vs. acródroma basal), pápus mais curto que a cipsela ( $v s$. pápus com o mesmo comprimento ou mais longo que a cipsela) e entrenós espaçados ( $v s$. folhas concentradas na base da planta). Calea aldamoides é morfologicamente relacionada também à $C$. abbreviata pelo hábito e pelo pápus menor que a cipsela, porém diferencia-se por possuir pecíolos de 4-9 mm compr., lâminas foliares lanceoladas e pubescentes ( $v s$. lâminas foliares sésseis, lineares e glabras) (Silva et al. 2016).

3. Calea candolleana (Gardner) Baker, Fl. bras. 6(3): 256. 1884.

Iconografia: Roque \& Carvalho (2011: 551, Fig. 1)

Subarbustos eretos, 0,7-1,3 m alt. Folhas opostas; pecíolos 3-6 mm compr.; lâmina elíptica a oblonga, 1,6-6,5 × 0,6-2,5 cm, venação actinódroma basal, ápice agudo, base aguda, margem serreada, face adaxial escabra, abaxial pubescente. Capitulescências corimbosodicasiformes. Capítulos radiados; pedúnculos 1,3$11 \mathrm{~cm}$ compr., pubescentes a velutinos. Invólucro campanulado, monomórfico, 0,9-1,1 × 0,6-1 cm, 4-seriado; brácteas involucrais escariosas, ovais a oblongas, $0,3-1,1 \times 0,2-0,4 \mathrm{~cm}$, ápice agudo, escabras. Eixo da inflorescência convexo; páleas planas, oblongas, 5-7,5 mm compr., ápice agudo. Flores do raio 7-11, corola amarela, tubo $2,5-4 \mathrm{~mm}$ compr., lâmina 7-9 × 3,5-7 mm, ápice 4-lobulado; estilete 4-5 mm compr., ramos do estilete $c a$. 1 $\mathrm{mm}$ compr. Flores do disco 28-32, corola amarela, 4,5-6 mm compr., glabra, tubo 1,2-2 mm compr., glanduloso, limbo 2-2,8 mm compr., lacínios 1,2$1,3 \mathrm{~mm}$ compr.; anteras $2-2,8 \mathrm{~mm}$ compr.; estilete 5-6 mm compr., ramos do estilete 1,6-2 mm compr. Cipselas, 4-angulosas, 2,8-4 mm compr., glabras; pápus de páleas livres, ovais, 0,3-0,5 mm compr. Material selecionado: BRASIL. GOIÁS: Niquelândia, Rodovia GO-237 de Niquelândia e Colinas do Sul, $c a$. de 34 km de Niquelândia, 16.III.2012, J. Bringel \& H.J.C. Moreira 940 (CEN, UB).

Distribuição, hábitat e fenologia: Tocantins, Pernambuco, Bahia, Mato Grosso, Goiás e Minas Gerais (BFG 2015). Em Goiás cresce em cerrado s.s. principalmente ao noroeste e também no centro do estado em elevações entre 370 e 1.000 m. Fértil de outubro a maio.

Das espécies ocorrentes em Goiás a que mais se assemelha com Calea candolleana é $C$. elongata, pois ambas apresentam capitulescência dicasiforme, invólucro campanulado e capítulos radiados. Calea candolleana diferencia-se, contudo, de C. elongata pelas folhas pecioladas ( $v s$. sésseis), pelos pedúnculos pubescentes a velutinos (vs. escabros), pelas páleas do eixo da inflorescêsncia planas e oblongas ( $v s$. contuplicadas e linear lanceoladas) e também por apresentar folhas com lâmina elíptica a oblonga com margem serreada ( $v s$. linear a oblanceolada com margem inteira a esparso-crenada).

4. Calea chapadensis Malme, Ark. Bot. 24A(8): 51. 1932

Fig. 1a-c

Subarbustos eretos, $35-70 \mathrm{~cm}$ alt. Folhas verticiladas; sésseis; lâmina elíptica, 2,8-7,8 × $1,1-4 \mathrm{~cm}$, venação actinódroma suprabasal, ápice agudo, base aguda, margem crenada a crenulada, face adaxial pubescente, abaxial tomentosa. Capítulescência umbeliforme. Capítulos discoides; 


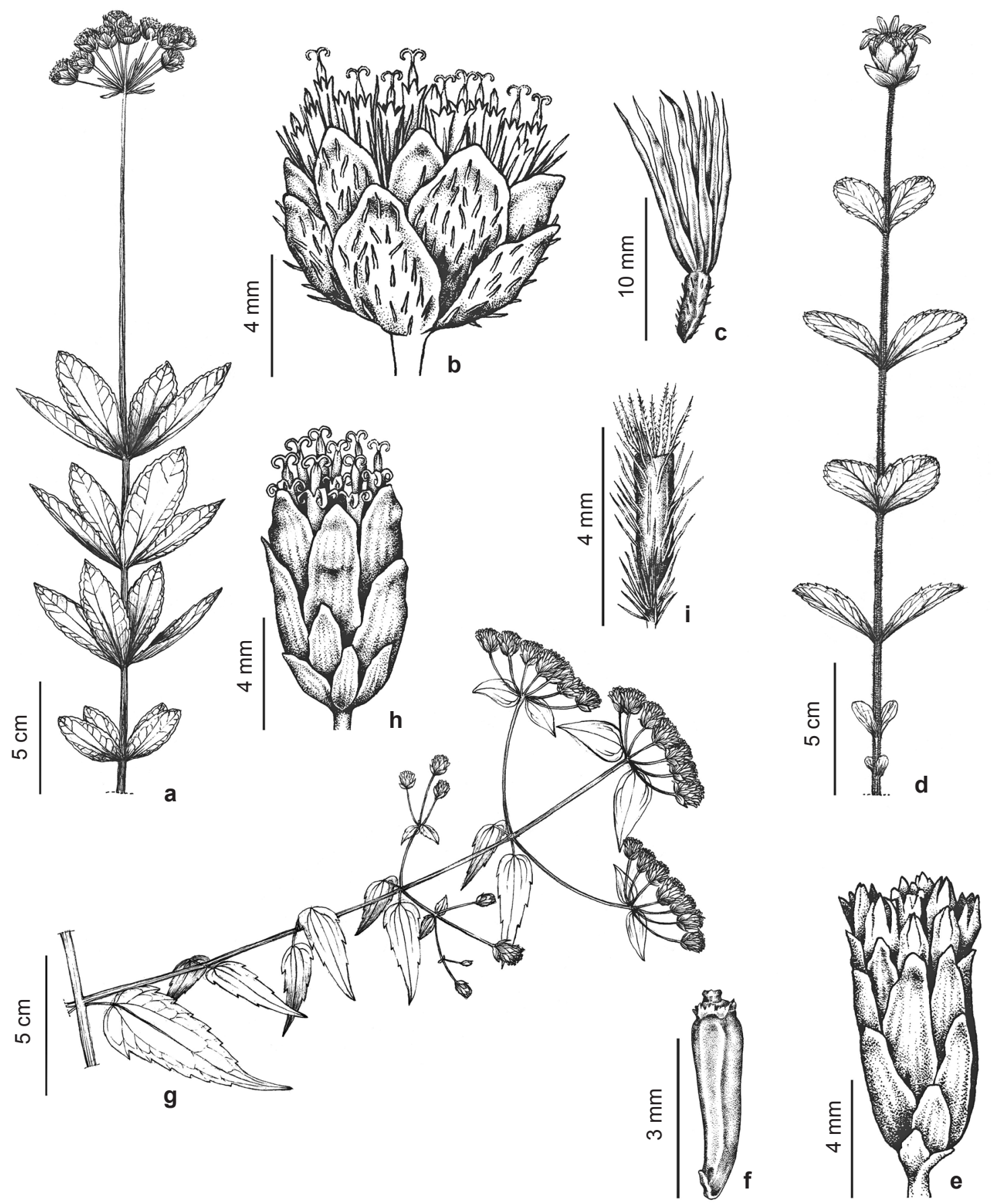

Figura 1 - a-c. Calea chapadensis - a. hábito; b. capítulo; c. cipsela. d. C. cuneifolia - d. hábito. e, f. C. diffusa - e. capítulo; f. cipsela. g-i. C. divergens - g. ramo fértil; h. capítulo; i. cipsela. [a-c. desenhados de Macedo et al. 3340 (UB); d. desenhado de Pastore \& Bringel 676 (CEN); e,f. desenhados do holótipo; g-i. desenhados de Silva \& de Jesus 3043 (UFG)].

Figure 1 -a-c. Calea chapadensis - a. habit; b. capitulum; c. cypsela. d. C. cuneifolia - d. habit. e, f. C. diffusa-e. capitulum; f. cypsela. g-i. C. divergens - g. flowering branch; h. capitulum; i. cypsela. [a-c. drawed from Macedo et al. 3340 (UB); d. drawed from Pastore \& Bringel 676 (CEN); e,f. drawed from the holotype; g-i. drawed from Silva \& de Jesus 3043 (UFG)]. 
pedúnculos 1,5-5,7 cm compr., velutinos. Invólucro campanulado, dimórfico, $0,8-0,9 \times 1-1,3 \mathrm{~cm}$, 2-seriado; série externa de 3-4 brácteas involucrais foliáceas, oblongas, 8-8,5 ×3-5 mm, ápice agudo, margem serreada, pubescentes; série interna de brácteas involucrais escariosas, oblongas, 7-8,5 $\times 3,5-5 \mathrm{~mm}$, ápice agudo, pubescentes. Eixo da inflorescência cônico; páleas conduplicadas, oblongas, 4,5-5 mm compr., ápice agudo. Flores 26-36, corola amarela, ca. $6 \mathrm{~mm}$ compr., glabra, tubo 2,5-3 mm compr., limbo 0,8-1 mm compr., lacínios 2-2,7 $\mathrm{mm}$ compr.; anteras $2-3 \mathrm{~mm}$ compr.; estilete $6-6,5 \mathrm{~mm}$ compr., ramos do estilete 1-1,5 mm compr. Cipselas obcônicas, $c a$. $3 \mathrm{~mm}$, pubescentes; pápus de páleas livres linearlanceoladas, $c a .6 \mathrm{~mm}$ compr.

Material selecionado: BRASIL. GOIÁS: Aragarças, Fazenda de Gerald Dao, $c .150 \mathrm{~km}$ on the road S. of base camp., $15^{\circ} 51^{\prime}$ 'S, $52^{\circ} 15^{\prime}$ 'W, 8.XI.1968, R.M. Harley \& $R$. Souza 10954 (UB).

Distribuição, hábitat e fenologia: Mato Grosso, Goiás e Mato Grosso do Sul. Ocorre em cerrado s.S. em elevações entre 800 e $1.000 \mathrm{~m}$ no estado de Goiás. Fértil no mês de novembro.

Calea chapadensis pode ser confundida com C. reticulata pelo fato de ambas apresentarem capítulos discoides, capitulescência umbeliforme e folhas verticiladas. Entretanto, a primeira apresenta lâmina foliar com face abaxial tomentosa e face adaxial pubescente ( $v s$. escabra em ambas as faces), eixo da inflorescência cônico e com páleas oblongas ( $v s$. convexo e com páleas obovais). Além disso, o indumento de $C$. chapadensis confere à planta uma coloração esbranquiçada, o que não ocorre em C. reticulata.

\section{Calea cuneifolia DC., Prodr. 5: 674. 1836.}

Fig. 1d

Subarbustos eretos, $35-45 \mathrm{~cm}$ alt. Folhas opostas, sésseis; lâmina oboval, 2,9-7,3 × 1,6-4,5 $\mathrm{cm}$, venação actinódroma basal, ápice obtuso ou arredondado, base cuneada, margem serreada, velutina em ambas as faces. Capítulos solitários, radiados; pedúnculos 8,7-24 cm compr., velutinos. Invólucro campanulado, dimórfico, 1,5-1,6 $\times$ 1,7-1,8 cm, 3-4-seriado; 1 série externa de 2-3 brácteas involucrais foliáceas, ovais a orbiculares, $8-1,3 \times 0,7-1 \mathrm{~cm}$, ápice obtuso a arredondado, margem serreada a inteira, velutinas; $2-3$ séries internas de brácteas involucrais escariosas, ovais a elípticas, $0,9-1,6 \times 0,5-0,8 \mathrm{~cm}$, ápice agudo a obtuso, glabras. Eixo da inflorescência convexo; páleas planas, lineares, 1,2-1,5 cm compr., ápice agudo. Flores do raio 9-12, corola amarela, tubo 5,8-7,3 mm compr., lâmina 9-20×3-6 mm, ápice 4-lobulado; estilete 9-10 $\mathrm{mm}$ compr., ramos do estilete 1,9-2,7 mm compr. Flores do disco 42-70, corola amarela, $8,6-9,7 \mathrm{~mm}$ compr., glabra, tubo 3,7-4 mm compr., limbo 3-3,5 mm compr., lacínios 1,6-2,3 mm compr.; anteras 3,2-3,6 mm compr.; estilete $0,9-1 \mathrm{~cm}$ compr., ramos do estilete $2-2,5$ $\mathrm{mm}$ compr. Cipselas obovoides, 4-angulosas, $c a$. 3,7 mm compr., seríceas; pápus de páleas livres, lineares a linear-lanceoladas $c a .9 \mathrm{~mm}$ compr.

Material selecionado: BRASIL. GOIÁS: Planaltina, Sítio São José, 27.IX.2011, J.M. Silva, J. Cordeiro \& E. Barbosa 7984 (MBM).

Distribuição, hábitat e fenologia: Distrito Federal, Goiás, Mato Grosso, Mato Grosso do Sul, Minas Gerais, Paraná e São Paulo (BFG 2015). Em Goiás ocorre em cerrado s.s. e campo limpo entre elevações de 800 e 1.000 m. Fértil em setembro e outubro.

Calea cuneifolia assemelha-se morfologicamente à $C$. multiplinervia por ambas se tratarem de subarbustos com capítulos solitários e radiados, com sistema subterrâneo desenvolvido. Porém, C. cuneifolia se diferencia de C. multiplinervia pelas folhas com lâmina oboval (vs. lâmina linear, lanceolada ou elíptica), pela presença de brácteas involucrais externas foliáceas (vs. ausência) e pelo pápus com ca. $9 \mathrm{~mm}$ compr. (vs. 5,5-6 mm compr.)

6. Calea diffusa Pruski, Phytoneuron 72: 11. 2013.

Fig. 1e,f

Subarbustos a arbustos eretos, $0,6-1,3 \mathrm{~m}$ alt. Folhas opostas; pecíolos 1-3 mm compr.; lâmina estreito-elíptica a lanceolada, 1-3,5 × 0,3-1,3 $\mathrm{cm}$, venação craspedródoma, ápice agudo, base aguda, margem crenada a serreada, escabra em ambas as faces. Capitulescência corimbosodicasiforme. Capítulos discoides; pedúnculos 0,5-2,6 cm compr., glabros. Invólucro cilíndrico, monomórfico, 6,9-8 × 4-5,3 mm, 3-seriado, brácteas involucrais escariosas, ovais a elípticas, 1,6-7 × 1,5-3 mm, ápice agudo, glabras, manchas vináceas. Eixo da inflorescência convexo; páleas planas, lineares, 6-6,6 mm compr., ápice agudo. Flores 9-10, corola amarela, 4-4,5 mm compr., glabra, tubo 1,8-2 mm compr., limbo 1,4-1,7 $\mathrm{mm}$, lacínios 1,2-1,7 mm compr.; anteras $c a$. 2,2 $\mathrm{mm}$ compr.; estilete $c a$. 4,2 $\mathrm{mm}$ compr., ramos do estilete $c a$. 1,3 mm compr. Cipselas 4-angulosas, 3,2-3,7 mm compr., glabras; pápus de páleas livres, ovais de base enegrecida, $c a$. $0,3 \mathrm{~mm}$ compr. 
Material selecionado: BRASIL. GOIÁS, estrada para Araí, 1088 m, 1340'16.8”S, 47²8'30.2”W, 13.IV.2004, M.L. Fonseca et al. 5033 (Holótipo IBGE).

Distribuição, hábitat e fenologia: Endêmica da região norte da cadeia de montanhas VeadeirosAraí no município de Cavalcante no estado de Goiás onde cresce em campo limpo, campo rupestre e cerrado rupestre, em elevações entre $1.088 \mathrm{e}$ $1.128 \mathrm{~m}$. Fértil de fevereiro a maio.

Por apresentar capítulos dispostos em capitulescências corimboso-dicasiformes, e pequenos capítulos discoides $(6-7 \times 5-6,7 \mathrm{~mm})$, Calea diffusa pode ser comparada a $C$. robinsoniana e C. polycephala. Diferindo de C. robinsoniana pelas folhas pecioladas e lâmina mais curta com até $3,5 \mathrm{~cm}$ compr. (vs. sésseis, com lâmina até 18 $\mathrm{cm}$ compr.), eixo da inflorescência paleáceo ( $v s$. epaleáceo) e pápus $c a$. $0,3 \mathrm{~mm}$ compr. (vs. pápus com 0,8-1,9 mm compr.) e de C. polycephala por possuir folhas com base aguda e invólucro 3-seriado com manchas vináceas ( vs. base obtusa e invólucro 4-seriado esverdeado).

7. Calea divergens Sch.Bip. ex Baker, Fl. bras. 6(3): 262. 1884.

Fig. $1 \mathrm{~g}-\mathrm{i}$

Subarbustos eretos, 1-2 m alt, apoiantes ou raro trepadeiras. Folhas opostas; pecíolos 3,3-9 mm compr.; lâmina lanceolada, 2,6-7,7 × 1,2-3,8 $\mathrm{cm}$, venação actinódroma suprabasal, ápice agudo, base obtusa a arredondada, margem serreada, face adaxial escabra, abaxial glabra. Capitulescência umbeliforme. Capítulos discoides; pedúnculos até $8,6 \mathrm{~mm}$ compr., glabros. Invólucro cilíndrico, monomórfico, 6-8,5 × 3,4-4,4 mm; 4-seriado, brácteas involucrais escariosas, ovais a elípticas, 2,2-7 × 1,5-2,8 mm, ápice agudo, glabras. Eixo da inflorescência plano; páleas conduplicadas, oblanceoladas, 6-6,7 mm compr., ápice obtuso, 3-dentado. Flores 10-14, corola amarela, 5-5,4 mm compr., glabra, tubo 1,8-2 mm compr., limbo 0,5-0,9 mm compr., lacínios 1,9-2,4 mm compr.; anteras 1,9-2,2 mm compr.; estilete 4,5-6,3 mm compr., ramos do estilete 1,4-1,9 mm compr. Cipselas estreito obcônicas, 3,3-3,7 mm compr., velutinas; pápus de páleas livres, lineares, 1,9-2,3 mm compr.

Material selecionado: BRASIL. GOIÁS: Niquelândia, Macedo $c a .3 \mathrm{~km}$ abaixo da mina de níquel à esquerda, 14'22'05"S, 48²3'04'W, 28.VI.1996, M.L. Fonseca et al. 1032 (IBGE).

Distribuição, hábitat e fenologia: Goiás, Distrito Federal e Minas Gerais (BFG 2015). Ocorre em cerrado s.s., floresta semidecídua, floresta ciliar, floresta de galeria e cerradão, em elevações de $c a$. $430 \mathrm{~m}$ no estado de Goiás. Fértil em maio e junho no estado de Goiás.

Das espécies aqui tratadas Calea divergens divide com $C$. lantanoides características como hábito subarbustivo, folhas pecioladas, capítulescências umbeliformes e capítulos discoides. Contudo, $C$. divergens difere de $C$. lantanoides por apresentar lâmina foliar lanceolada com face abaxial glabra ( $v s$. oval com face adaxial velutina), pedúnculos glabros ( $v s$. pedúnculos velutinos) e 10-14 flores por capítulo (vs. 5-6 flores). Além disso, o comprimento do pápus (1,9-2,3 mm compr.) em $C$. divergens é menor que o do pápus (3,7-4,6 mm compr.) de $C$. lantanoides.

8. Calea elongata (Gardner) Baker, Fl. bras. 6(3): 255. 1884.

Figs. 2a; 3a,b

Subarbustos eretos, 0,3-1,5 $\mathrm{m}$ alt. Folhas opostas, sésseis; lâmina linear a oblanceolada, $1,3-8,3 \times 0,2-2 \mathrm{~cm}$, venação acródroma suprabasal, ápice agudo a obtuso, base aguda, margem esparsocrenada, escabra em ambas as faces. Capitulescência dicasiforme. Capítulos radiados; pedúnculos 1-12 $\mathrm{cm}$ compr., escabros. Invólucro campanulado, monomórfico, 7,2-8,6 × 5,3-6,8 mm, 4-5-seriado; brácteas involucrais escariosas, ovais a oblongas, 2-7,7 $\times 2-3,6 \mathrm{~mm}$, ápice agudo enegrecido, escabras. Eixo da inflorescência convexo; páleas conduplicadas, linear-lanceoladas, 6-7 mm compr., ápice agudo. Flores do raio 7-9, corola amarela, tubo 3,2-4,9 mm compr., lâmina 5-9 × 4,2-5 mm, ápice 4-lobulado; estilete 3,5-4,7 mm compr., ramos do estilete $0,8-1,2 \mathrm{~mm}$ compr. Flores do disco 14-30, corola amarela, 4-6 mm compr., glabra, tubo 1,4-2,4 mm compr., limbo 1,9-2,5 mm compr., lacínios 0,6-1,1 mm compr.; anteras 2-2,3 mm compr.; estilete 4-5,7 mm compr., ramos do estilete $c a .1 \mathrm{~mm}$ compr. Cipselas subcilíndricas a 4-angulosas, 1,6-3 mm compr., glabras; pápus de páleas livres ovais, $0,5-0,8 \mathrm{~mm}$ compr.

Material selecionado: BRASIL. GOIÁS: Alto Paraíso de Goiás, Chapada dos Veadeiros, Descida para o Rio Preto, 29.IX.2012, G.H. Silva, M.J. Silva \& R.C. Sodré 113 (UFG).

Distribuição, hábitat e fenologia: Bahia, Goiás e Tocantins (BFG 2015). Em Goiás cresce em cerrado rupestre, campo limpo, campo sujo, vereda e floresta de galeria entre elevações de 450 a 1.550 m. Fértil de janeiro a março e de maio a novembro.

Calea elongata pode ser relacionada morfologicamente a $C$. gardneriana pelo hábito subarbustivo e pelos capítulos pequenos $(5-10 \times$ 

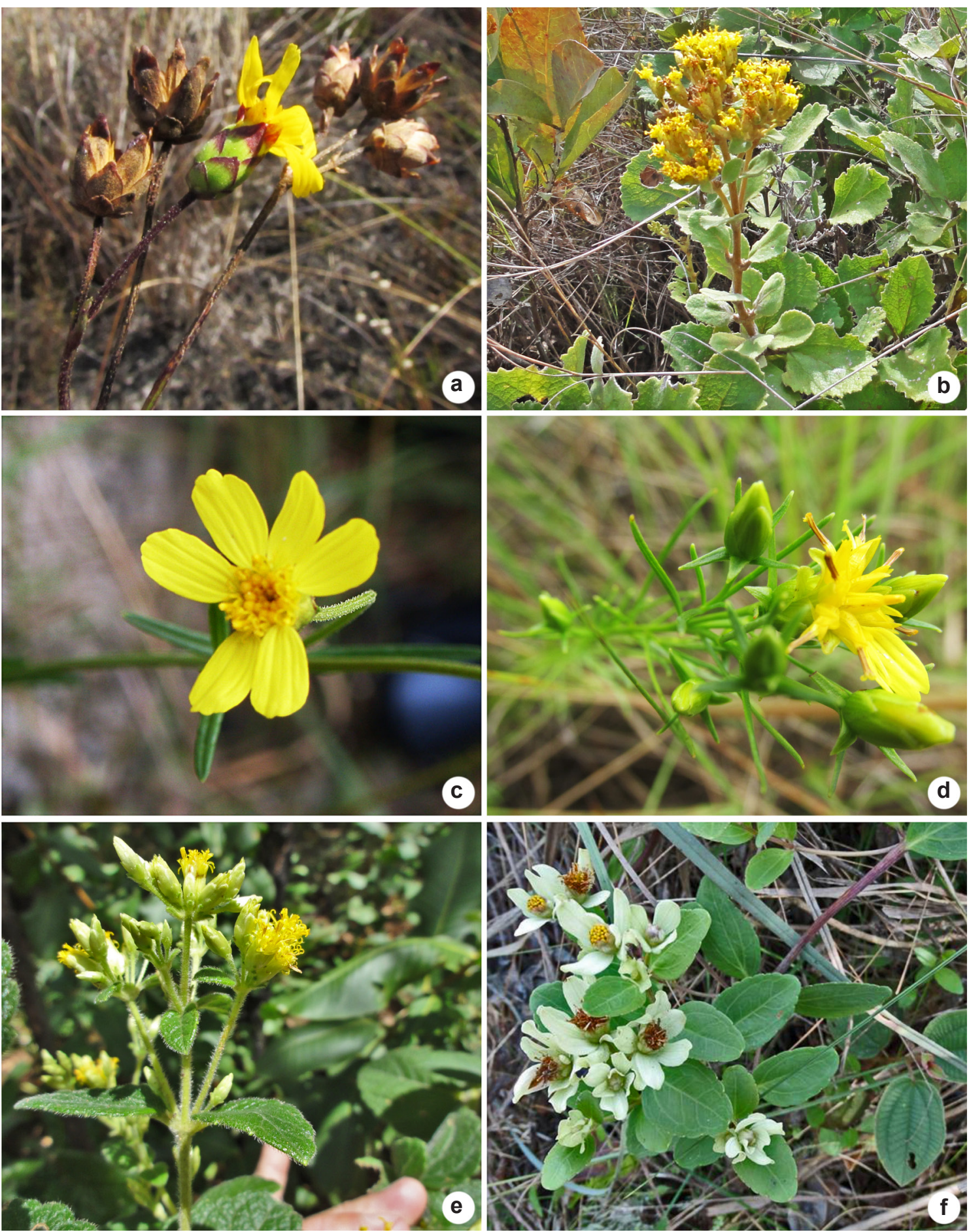

Figura 2 - a. Calea elongata - capítulos. b. C. fruticosa-aspecto geral. c. C. gardneriana-capítulo. d. C. hymenolepis - detalhe dos capítulos. e. C. lantanoides - capitulescência. f. C. lutea - hábito.

Figure 2 - a. Calea elongata - capitula. b. C. fruticosa - general aspect. c. C. gardneriana - capitulum. d. C. hymenolepis - capitula in detail. e. C. lantanoides - capitulescence. f. C. lutea - habit. 

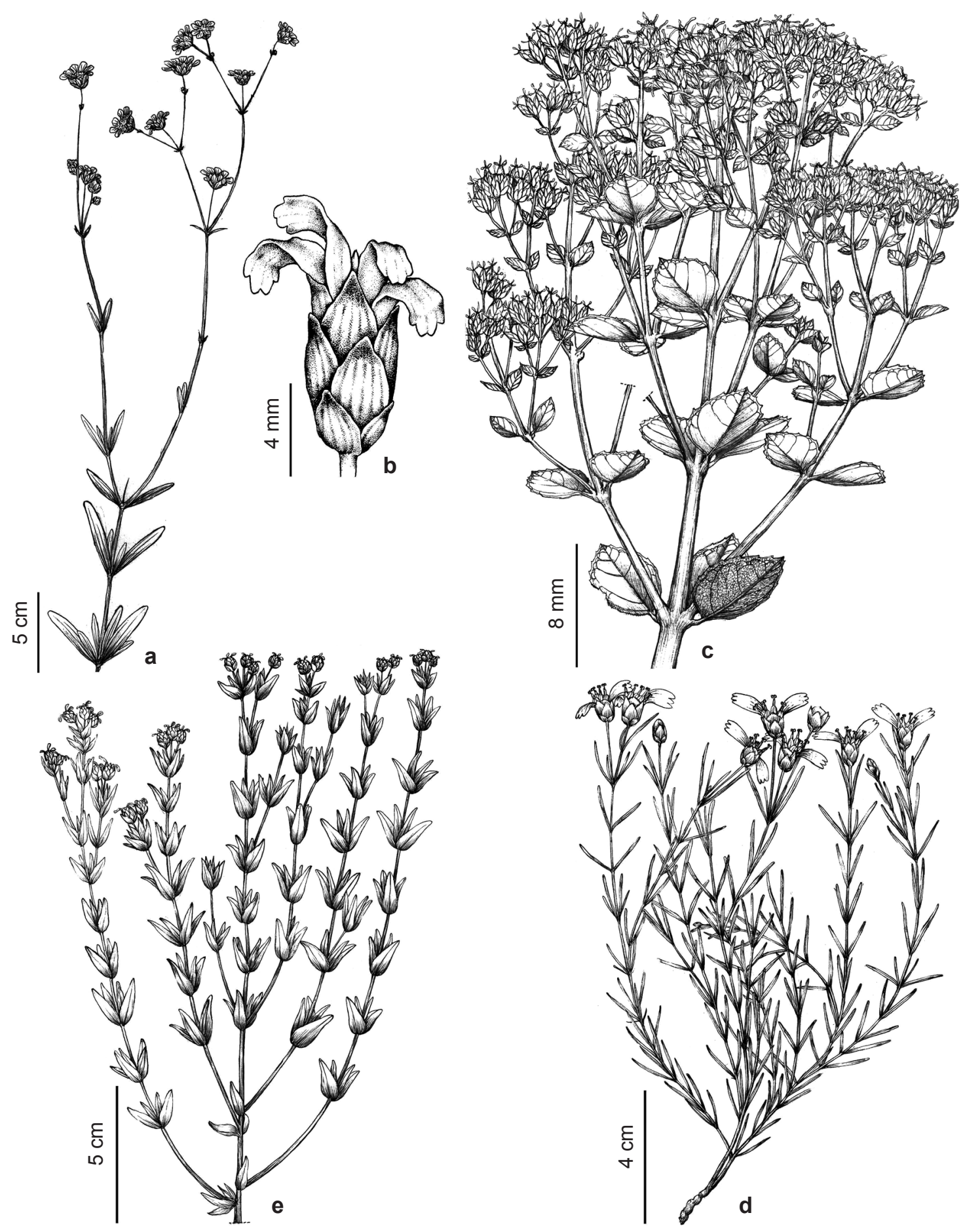

Figura 3 - a,b. Calea elongata - a. hábito; b. capítulo. c. C. fruticosa - hábito. d. C. hymenolepis - hábito. e. C. hypericifolia - hábito. [a,b. desenhados de Bringel \& Moreira 758 (UB); c. desenhado de Silva et al. 162 (UFG); d. desenhado de Silva et al. 117 (UFG); e. desenhado de Mendonça et al. 5364 (IBGE, UB)].

Figure 3 - a,b. Calea elongata - a. habit; b. capitulum. c. C. fruticosa - habit. d. C. hymenolepis - habit. e. C. hypericifolia - habit. [a, b. drawed from Bringel \& Moreira 758 (UB); c. drawed from Silva et al. 162 (UFG); d. drawed from Silva et al. 117 (UFG); e. drawed from Mendonça et al. 5364 (IBGE, UB)]. 
5-7 mm) e radiados, dispostos em capitulescências dicasiformes. Porém, C. elongata apresenta lâmina foliar linear a oblanceolada, com venação acródroma suprabasal (vs. linear com venação semicraspedódroma) e brácteas involucrais escabras com ápice enegrecido ( $v s$. glabras com ápice esverdeado). Além disso, uma característica frequente em C. gardneriana é a presença de gemas axilares desenvolvidas dando uma falsa impressão de que as folhas apresentam filotaxia verticilada, característica não encontrada em $C$. elongata.

9. Calea fruticosa (Gardner) Urbatsch, Zlotsky \& Pruski, Syst. Bot. 11(4): 506. 1986. Figs. 2b; 3c

Subarbustos a arbustos eretos, 1-2 m alt. Folhas opostas, alternas; pecíolos 2-9 mm; lâmina elíptica a orbicular, 1,2-7,9 × 1-4,8 cm, venação actinódroma suprabasal, ápice agudo a arredondado, base aguda a obtusa, margem denteada a denticulada, escabra em ambas as faces. Capitulescência corimboso-dicasiforme. Capítulos discoides; pedúnculos até $6 \mathrm{~mm}$ compr., velutinos. Invólucro cilíndrico, monomórfico, 0,9-1,1 $\times$ 0,3-0,4 mm, 4-5-seriado, brácteas involucrais escariosas, lanceoladas a estreito elípticas, 0,3-1 $\times 0,1-0,3 \mathrm{~cm}$, ápice agudo, externas velutinas, internas glabras. Eixo da inflorescência cônico; páleas conduplicadas, elípticas, $0,7-1 \mathrm{~cm}$ compr., ápice agudo. Flores 4-6, corola amarela, 5,8-6,8 $\mathrm{mm}$ compr., tubo $2-3 \mathrm{~mm}$ compr., glanduloso, limbo 1,2-2 mm compr., lacínios 1,8-2,6 mm compr.; anteras 2,6-3 mm compr.; estilete 6,8-7,2 $\mathrm{mm}$ compr., ramos do estilete $1,3-2,2 \mathrm{~mm}$ compr. Cipselas 4-angulosas, 4,4-6 mm, glandulosovelutinas; pápus de páleas livres, lineares, 1,7-3 mm compr.

Material selecionado: BRASIL. GOIÁS: Campo Alegre de Goiás, rodovia BR-050, 17 20 '45”S, 47047'26”'W, 12.IV.2013, M.L. Brotto et al. 985 (MBM). Distribuição, hábitat e fenologia: Distrito Federal, Goiás e Minas Gerais (BFG 2015). Cresce em cerrado s.s. e campo sujo entre 945 e $1.150 \mathrm{~m}$ de elevação em Goiás. Fértil de abril a setembro.

Calea fruticosa possui aspecto vegetativo semelhante ao de $C$. sickii e se diferencia desta última por apresentar capítulos com invólucro cilíndrico com 4-6 flores por capítulo ( $v s$. obcônico e 13-18 flores) e pápus de páleas livres (vs. coroniforme). As cipselas velutinas e com grande quantidade de tricomas glandulosos de C. fruticosa formam um tipo de indumento único entre as cipselas das espécies aqui estudadas.
10. Calea gardneriana (Gardner) Baker, Fl. bras. 6(3): 255. 1884.

Fig. 2c

Subarbustos eretos, 0,5-1 m alt. Folhas opostas à falsamente verticiladas pela presença de gemas axilares desenvolvidas; sésseis; lâmina linear, $1-7 \times 0,1-0,6 \mathrm{~cm}$, venação semicraspedódroma, ápice agudo, base aguda, margem inteira, escabra em ambas as faces. Capítulescências dicasiformes. Capítulos radiados; pedúnculos $0,6-6 \mathrm{~cm}$ compr., escabros. Invólucro campanulado, monomórfico, 0,5-1 $\times 0,5-0,8 \mathrm{~cm}, 5$-seriado; brácteas involucrais escariosas, ovais a oblongas, $2-9 \times 2-3,5 \mathrm{~mm}$, ápice agudo, glabras. Eixo da inflorescência convexo; páleas conduplicadas, oblanceoladas, 6-8 mm compr., ápice acuminado. Flores do raio 5-6, corola amarela, tubo 2-3 mm compr., lâmina 5,4-7,2 × 3-4 mm, ápice 4-lobulado; estilete 3-4 $\mathrm{mm}$ compr., ramos do estilete $1-1,5 \mathrm{~mm}$ compr. Flores do disco 24-28, corola amarela, 4-4,6 mm compr., tubo 1-1,5 mm compr., glanduloso, limbo 1,5-2 mm, lacínios 1-1,5 mm compr.; anteras 2-2,8 mm compr.; estilete $4-5 \mathrm{~mm}$ compr., ramos do estilete 1-1,5 mm compr. Cipselas subcilíndricas a 4-angulosas, 3-4,5 mm., glabras; pápus de páleas livres, ovais, 0,3-0,5 $\mathrm{mm}$ compr.

Material selecionado: BRASIL. GOIÁS: Goiás, Serra Dourada, Reserva Biológica Prof. José Ângelo Rizzo. Proximidades da antiga pedra Goiana, 14.V.2014, G.H. Silva, M.J. Silva \& R.C. Sodré 116 (UFG).

Distribuição, hábitat e fenologia: Tocantins, Bahia, Mato Grosso e Goiás (Roque \& Carvalho 2011). Em Goiás ocorre em cerrado rupestre e em campo rupestre, em elevações de 1.000 a 1.105 m. Fértil em dezembro e de março a junho.

Calea gardneriana é morfologicamente semelhante a $C$. elongata e a $C$. candolleana, pois as três apresentam capítulos radiados, invólucros com tamanhos semelhantes, ausência de brácteas involucrais foliáceas e pápus geralmente menor que $1 \mathrm{~mm}$ compr. Calea gardneriana pode ser diferenciada de C. candolleana por apresentar folhas sésseis com lâmina linear (vs. pecioladas com lâmina elíptica a oblonga), e distingue-se de $C$. elongata pelos caracteres mencionados nos comentários para esta espécie.

11. Calea hymenolepis Baker, Fl. bras. 6(3): 257. 1884.

Figs. 2d; 3d

Ervas eretas ou decumbentes, $10-40 \mathrm{~cm}$ alt. Folhas opostas e alternas; sésseis; lâmina linear, 0,9-3,5 × 0,1-0,2 cm, venação uninérvea, ápice agudo, base aguda, margem inteira, glabra em ambas as faces. Capítulescência corimbiforme. 
Capítulos radiados; pedúnculos 0,5-3,3 cm compr., glabros. Invólucro cilíndrico, monomórfico, 7-9 $\times$ 3,5-4,7 mm, 3-seriado; brácteas involucrais escariosas, lanceoladas a elípticas, 2,3-8 $\times$ 1,3-3 mm, ápice agudo a obtuso, glabras. Eixo da inflorescência convexo; páleas conduplicadas, lineares, 6-8 mm compr., ápice agudo. Flores do raio $1-2$, corola amarela, tubo $2-3 \mathrm{~mm}$ compr., lâmina 5,4-6,5 × 3-3,7 mm, ápice 3-lobulado; estilete 5-6 mm compr., ramos do estilete $0,4-0,5$ $\mathrm{mm}$ compr. Flores do disco 5-9, corola amarela, 4,6-5,2 mm compr., glabras, tubo 1,5-2 mm, limbo 0,7-1 mm, lacínios 2-3 mm compr.; anteras 2-2,8 mm compr.; estilete 4,4-6 mm compr., ramos do estilete 0,4-0,6 mm compr. Cipselas subcilíndricas a 4-angulosas, 3,4-4,5 × 1-1,3 mm., glabras; pápus de páleas livres, ovais, ca. 0,5 mm compr.

Material selecionado: BRASIL. GOIÁS: Pirenópolis, Parque Estadual dos Pireneus, arredores da guarita, 1315 m, 1548'10.3307'S, 4852'00.467'W, 9.IV.2015, G.H. Silva \& R.C. Teixeira 306 (UFG).

Distribuição, hábitat e fenologia: Mato Grosso, Goiás, Distrito Federal, Minas Gerais, São Paulo e Paraná (BFG 2015). Em Goiás ocorre em campo rupestre, campo limpo, campo sujo, cerrado s.s. entre 700 a $1.231 \mathrm{~m}$, espécie relativamente comum e bem distribuída pelo estado. Fértil de fevereiro a julho.

A morfologia de Calea hymenolepis, por apresentar lâminas foliares lineares (1-2 mm larg.), lembra a de C. elongata, C. gardneriana e C. ramosissima. No entanto, difere das três por apresentar 1-2 flores do raio por capítulo (vs. 7-9 em C. elongata, 5-6 em C. gardneriana e 4-7 em C. ramosíssima) e folhas com venação uninérvea (vs. acródroma suprabasal em C. elongata, semicraspedódroma em C. gardneriana e camptódroma em C. ramosissima). Pode, ainda, ser diferenciada de $C$. elongata e $C$. gardneriana pelas brácteas involucrais externas foliáceas (vs. brácteas involucrais foliáceas ausentes) e, ainda, de C. ramosissima por apresentar lâmina foliar glabra em ambas as faces (vs. estrigosa em ambas as faces).

12. Calea hypericifolia (Gardner) Baker, Fl. bras. 6(3): 258. 1884.

Fig. 3e

Ervas eretas, 20-40 cm alt. Folhas opostas; sésseis; lâmina lanceolada, 0,8-1,8 × 0,3-0,9 $\mathrm{cm}$, venação actinódroma basal, ápice agudo, base obtusa, margem inteira a serreada, escabra em ambas as faces. Capítulescência dicasiforme. Capítulos radiados; pedúnculos $0,4-1,3 \mathrm{~cm}$ compr., escabros. Invólucro campanulado, dimórfico, 7-7,8 $\times$ 3,5-5,5 mm, 4-seriado; 1 série externa de 2-4 brácteas involucrais foliáceas, elípticas, 2,7-5,6× 1,9-2,7 mm, ápice agudo, margem inteira, escabras; 3 séries internas de brácteas involucrais escariosas, ovais a elípticas, 2,4-7,6 × 2-3 mm, ápice agudo, glabras. Eixo da inflorescência convexo, paleáceo; páleas planas, lineares, $c a$. 5,5 mm compr., ápice agudo. Flores do raio 6-7, corola amarela, tubo ca. 1,9 mm compr., lâmina ca. $4 \times 1,9 \mathrm{~mm}$, ápice 3-lobulado; estilete ca. 4,2 mm compr., ramos do estilete ca. 0,5 mm compr. Flores do disco 8-13, corola amarela, 4,4-4,8 mm compr., glabra, tubo 1,5-1,6 mm, limbo 0,8-1 mm, lacínios 2,1-2,2 mm compr.; anteras ca. 2,1 mm compr.; estilete 4,6-5,3 mm compr., ramos do estilete $0,7-0,8 \mathrm{~mm}$ compr. Cipselas 4-angulosas, 2,4-3 mm., glabras; pápus de páleas livres, ovais, ca. 0,3 mm compr.

Material selecionado: BRASIL. GOIÁS: Vila Boa, BR-020 em direção a Flores de Goiás, estrada de chão, entrada para a fazenda Santa Luzia, 14 ${ }^{\circ} 56^{\prime} 44.7^{\prime \prime}$, 4701'19.4"W, 18.III.2003, R.C. Mendonça et al. 5364 (IBGE, UB).

Distribuição, hábitat e fenologia: Tocantins, Goiás e Minas Gerais (BFG 2015). Em Goiás ocorre em cerrado s.s. em elevações de 480-512 m. Fértil nos meses de março e junho.

Essa espécie compartilha três características com espécies do grupo Calea teucriifolia (Pruski \& Urbatsch 1987), capítulos $(<1,5 \mathrm{~cm}$ compr. e $<1$ $\mathrm{cm}$ larg.) e folhas pequenas ( $<5 \mathrm{~cm}$ compr.), pápus curtíssimo ( $<1 \mathrm{~mm}$ compr.) e brácteas involucrais externas foliáceas. Diferencia-se das espécies do referido grupo por possuir lâmina foliar lanceolada com base obtusa e escabras (vs. elíptica a rômbica ou oblanceolada com base aguda e pubescente a tomentosa) e páleas do eixo da inflorescência planas e lineares (vs. conduplicadas e oblongas).

13. Calea irwinii G.M.Barroso, Sellowia 26: 108. 1975.

Iconografia: Barroso (1975: 116, Fig. 5)

Subarbustos eretos, ca. $1 \mathrm{~m}$ alt. Folhas opostas; pecíolos 1,5-2 mm; lâmina oval a elíptica, 1,4-7,2 × 0,6-3,6 cm, venação actinódroma suprabasal, ápice agudo, base obtusa, margem inteira, glabras em ambas as faces. Capitulescência corimboso-dicasiforme. Capítulos discoides; pedúnculos 2-7,6 cm compr., escabros. Invólucro campanulado, dimórfico, 1,2 × 0,8 cm, 3-seriado; 1 série externa de 2 brácteas involucrais foliáceas, ovais, 5-6 × 2,5-3,5 mm, glabras; 2 séries internas de brácteas involucrais escariosas, ovais 5-9×3-4,5 
$\mathrm{mm}$, ápice agudo, glabras. Eixo da inflorescência cônico; páleas oblongas, conduplicadas, $c a .1 \mathrm{~cm}$ compr., ápice obtuso. Flores $c a$. 22, corola amarela, ca. $6 \mathrm{~mm}$ compr., tubo ca. 3,4 mm compr., glabra, limbo $c a$. 1,3 mm compr., lacínios $c a$. 1,3 mm compr.; anteras $c a$. $2,5 \mathrm{~mm}$ compr.; estilete 7,5 mm compr., ramos do estilete $c a$. 1,5 mm compr. Cipselas 4-angulosas, $c a .4 \mathrm{~mm}$ compr., subglabras, tricomas apenas nos ângulos; pápus de páleas livres, $c a .2 \mathrm{~mm}$ compr.

Material examinado: BRASIL. GOIÁS: Alto Paraíso de Goiás, Chapada dos Veadeiros $5 \mathrm{~km}$ of Alto Paraíso, $1.500 \mathrm{~m}, 14^{\circ} \mathrm{S}, 47^{\circ} \mathrm{W}, 16 . \mathrm{II} .1979$, B. Gates \& G.F. Estabrook 225 (RB, UB); Chapada dos Veadeiros, campo and rocky slopes, $1.000 \mathrm{~m}$, H.S. Irwin 25002 (UB).

Distribuição, hábitat e fenologia: Endêmica da Chapada dos Veadeiros no estado de Goiás onde cresce em campo rupestre. Planta rara com apenas dois exemplares conhecidos desde sua descrição e classificada como espécie em perigo (Nakajima et al. 2014). Fértil em fevereiro.

A espécie em questão assemelha-se a Calea sickii, por ambas apresentarem capítulos discoides e capitulescências corimboso-dicasiformes. Contudo, C. irwinii se diferencia de C. sickii por apresentar lâmina foliar glabra ( $v s$. escabra), brácteas involucrais glabras (vs. brácteas involucrais com ápice flocoso), e pápus de páleas livres ( $v S$. coroniforme).

14. Calea lantanoides Gardner, London J. Bot. 7 : 416. 1848.

Fig. 2e

Subarbustos eretos, 1-1,5 $\mathrm{m}$ alt. Folhas opostas; pecíolo 3-7 mm compr.; lâmina oval, 1,9$7,6 \times 1,1-6,4 \mathrm{~cm}$, venação actinódroma suprabasal, ápice obtuso, base cordada a arredondada, margem serreada a crenada, face adaxial escabra, abaxial velutina. Capitulescência dicásio-umbeliforme ou umbeliforme-composta. Capítulos discoides; pedúnculos até 7,4 mm compr., velutinos. Invólucro cilíndrico, monomórfico, 6,3-7 × 3-3,9 mm, 4 -seriado, brácteas involucrais escariosas, ovais a oblongas, 1,3-5,5 × 1-2 mm, ápice obtuso, externas velutinas, internas glabras. Eixo da inflorescência convexo; páleas conduplicadas, oblongas, 6-7,4 mm compr., ápice obtuso eroso. Flores 5-6, corola amarela, 5,2-6,8 mm compr., glabra, tubo 2,5-3,1 mm compr., limbo 0,4-0,9 mm compr., lacínios 2,3-2,8 mm compr.; anteras 2,2-2,5 mm compr.; estilete 5-7,3 mm compr., ramos do estilete 1-1,5 $\mathrm{mm}$ compr. Cipselas obovoides, 1,8-2 mm compr., velutinas; pápus de páleas livres, lanceoladas, $3,7-4,6 \mathrm{~mm}$ compr.
Material selecionado: BRASIL. GOIÁS: Pirenópolis, Serra dos Pireneus, próximo à vereda, $1.126 \mathrm{~m}$, 15²9'2.364"S, 4853'58.654”'W, 19.XI.2015, G.H. Silva, N.V. Oliveira \& T.C. Freire 353 (UFG).

Distribuição, hábitat e fenologia: Tocantins, Maranhão, Mato Grosso, Goiás, Distrito Federal, Mato Grosso do Sul, Minas Gerais, São Paulo e (BFG 2015). No estado de Goiás ocorre em borda de floresta de galeria, cerradão, cerrado s.s. e campo limpo entre 620 e $1.126 \mathrm{~m}$. Fértil de março a junho.

Calea lantanoides é confundida com $C$. fruticosa principalmente quando herborizada, pois as duas espécies possuem lâmina foliar oval (variando de elíptica a orbicular em C. fruticosa), capítulos discoides com invólucro cilíndrico, e lâmina foliar com face adaxial escabra. Contudo, C. lantanoides se diferencia de C. fruticosa pela lâmina foliar com face abaxial velutina (vs. escabra), capitulescência umbeliformecomposta ou dicásio-umbeliforme ( $v s$. corimbosodicasiforme) e pela cipsela com 1,8-2 mm compr. (vs. 4-7 mm compr.).

15. Calea lutea Pruski \& Urbatsch, Brittonia 40(4): 353. 1988. Fig. $2 \mathrm{f}$

Subarbustos eretos, $1-1,5 \mathrm{~m}$ alt. Folhas opostas; pecíolo 2-6,5 mm compr.; lâmina elíptica, 1,7-5,5 × 0,6-2,7 cm, venação acródroma suprabasal, ápice agudo, base aguda a obtusa, margem crenada, glabra em ambas as faces. Capitulescência dicasio-umbeliforme. Capítulos discoides; pedúnculo 2-5,5 cm compr., glabro. Invólucro campanulado, dimórfico, $0,8-1,1 \times$ 0,5-0,8 cm, 4-seriado; 1 série externa com 4-5 brácteas involucrais foliáceas, estreito elípticas a elípticas, 0,9-1,9 × 0,4-0,7 cm glabras, alvas; 3 séries internas, brácteas involucrais escariosas, elípticas a oblongas, 6,8-10,5 ×3,4-3,9 mm, ápice agudo a obtuso, glabras. Eixo da inflorescência convexo; páleas conduplicadas, oblongas, 8-10 $\mathrm{mm}$, ápice agudo. Flores 12-21, corola amarela, 5,3-7 mm compr., glabra, tubo 2,2-2,7 mm compr., limbo 2,2-2,6 mm compr., lacínios 1,9-2,3 mm compr.; anteras 2,6-3,1 mm compr.; estilete 7,5-10 $\mathrm{mm}$ compr., ramos do estilete $1-1,9 \mathrm{~mm}$ compr. Cipselas 4-angulosas, 2,6-4 mm, glabras ou poucos tricomas no ápice; pápus de páleas livres, estreito lanceoladas, 4,3-6,4 mm.

Material examinado: BRASIL. GOIÁS: Serranópolis, RPPN Pousada das Araras, Morro Guardião/19, 620 m, 18²6'22"S, 51'59'43”', I.2005, L.F. Souza 1823 (HJ, UFG).

Material adicional selecionado: BRASIL. MATO GROSSO: Vila Bela da Santíssima Trindade, Fazenda 
Pelicano, caminho para a serra de Ricardo Franco, próxima ao rio Paraíso, $14^{\circ} 51>04 » \mathrm{~S}, 60^{\circ} 14>11 » \mathrm{~W}$, 20.III.2014, M.F. Simon et al. 2126 (UFG).

Distribuição, hábitat e fenologia: Pará, Mato Grosso, Goiás e Mato Grosso do Sul (Pruski \& Urbatsch 1988). Em Goiás ocorre em campo limpo úmido em elevações inferiores a $800 \mathrm{~m}$ de altitude na porção sudoeste do estado. Fértil de janeiro a março.

Calea lutea compartilha com $C$. lantanoides características como folhas pecioladas, capítulescências umbeliforme-compostas ou dicásio-umbeliformes, capítulos discoides e pápus mais comprido que a cipsela. Porém, $C$. lutea difere de $C$. lantanoides por possuir folhas e pedúnculos glabros (vs. folhas com face abaxial velutina, adaxial escabra e pedúnculos velutinos), invólucro campanulado de brácteas involucrais externas foliáceas ( $v s$. cilíndrico de brácteas involucrais externas escariosas), cipselas glabras ou com poucos tricomas ( $v s$. cipselas velutinas). Além disso, as brácteas involucrais alvas de $C$. lutea são únicas entre as espécies de Calea do estado de Goiás.

16. Calea mediterranea (Vell.) Pruski, Sida 21(4): 2024. 2005.

Fig. $4 a, b$

Subarbustos eretos, 0,45-1,5 m alt. Folhas verticiladas; sésseis; lâmina elíptica, 2,5-11 $\times$ 0,6-4,9 cm, venação actinódroma suprabasal, ápice agudo, base aguda, margem serreada, face adaxial escabra, abaxial velutina. Capitulescência umbeliforme. Capítulos radiados; pedúnculos 1,8$5,4 \mathrm{~cm}$ compr., velutinos. Invólucro campanulado, dimórfico, 0,8-1 × 0,8-1,4 mm, 2-seriado; 1 série externa de 3-5 brácteas involucrais foliáceas, elípticas, 7,5-9 × 3-4 mm, ápice agudo, margem serreada, escabras; 1 série interna, brácteas involucrais escariosas, oblongas, 7-9 × 3,3-4,1 $\mathrm{mm}$, ápice agudo, escabras. Eixo da inflorescência cônico; páleas conduplicadas, oblongas 6,5-7 mm compr., ápice obtuso, eroso. Flores do raio 3-5, corola amarela, tubo 2,5-3,5 mm compr., lâmina 4,5-5 × 2-3 mm, ápice 3-lobulado; estilete ca. 4,5 $\mathrm{mm}$ compr., ramos do estilete $c a$. $0,5 \mathrm{~mm}$ compr. Flores do disco 22-58, corola amarela, 5,5-7 mm compr., glabra, tubo 2-3,6 mm compr., limbo 0,81,4 mm compr., lacínios 2-2,6 mm compr.; anteras 2,2-3 mm compr.; estilete 5,6-8 mm compr., ramos do estilete 1,3-1,8 mm compr. Cipselas obovoides, 2,5-4 mm compr., velutinas; pápus de páleas livres, linear-lanceoladas, 4,4-6,7 mm compr.

Material selecionado: BRASIL. GOIÁS: Mossâmedes, Serra Dourada, arredores da nascente, 996 m,
1604'01.472"S, 50¹0'48.736”W, 17.II.2015, G.H. Silva et al. 214 (UFG).

Distribuição, hábitat e fenologia: Mato Grosso, Goiás, Distrito Federal, Minas Gerais, Espirito Santo, São Paulo e Paraná (BFG 2015). Em Goiás cresce entre 656 e 996 m em cerrado s.s., campo sujo e campo limpo. Fértil de novembro a fevereiro.

Folhas verticiladas, capitulescência umbeliforme e brácteas involucrais foliáceas são características compartilhadas por Calea mediterranea, C. chapadensis, C. quadrifolia e $C$. reticulata. Porém, $C$. mediterranea pode ser diferenciada de $C$. chapadensis e $C$. reticulata por possuir capítulos radiados ( $v s$. discoides) e lâmina foliar com face abaxial velutina e adaxial escabra (vs. face abaxial tomentosa em C. chapadensis e escabra em $C$. reticulata). Já o que diferencia a espécie em questão de $C$. quadrifolia é o seu invólucro 2-seriado (vs.4-5-seriado), lâmina da flor do raio 4,5-5 mm compr. (vs. 13-18 mm compr.) e páleas do pápus 4,4-6,7 mm compr., lanceoladas (vs. 1,6-2,7 mm compr., oblongas).

17. Calea multiplinervia Less., Linnaea 5(1): 159. 1830.

Figs. 4c,d; 5a

Subarbustos eretos, 25-60 cm alt. Folhas opostas, sésseis; lâmina linear-lanceolada, lanceolada ou elíptica, 2,1-16 × 0,5-4,5 cm, venação acródroma basal, ápice agudo, base aguda, margem serreada, hirsuta em ambas as faces. Capítulos solitários, radiados; pedúnculos 20-40 cm compr., hirsutos. Invólucro campanulado, monomórfico, 1,1-1,4 × 0,9-1,5 cm, 3-seriado, brácteas involucrais escariosas, lanceoladas a oblongas, 6-13 × 3-6 mm, ápice agudo, glabras. Eixo da inflorescência convexo; páleas planas, lineares, 0,7-1 cm compr., ápice agudo. Flores do raio 6-14, corola amarela, tubo 4-4,5 mm compr., lâmina 14-20 × 4-5 mm, ápice 4-lobulado; estilete 6,5-7 mm compr., ramos do estilete $1-2 \mathrm{~mm}$ compr. Flores do disco 22-62, corola amarela, 5-6 mm compr., tubo 2-2,4 mm compr., glabra, limbo 2-2,7 mm compr., lacínios 0,6-0,9 mm compr.; anteras 2,3-3 mm compr.; estilete 7-7,5 mm compr., ramos do estilete 1-1,5 mm compr. Cipselas 4-angulosas, 4-4,5 mm compr., glabras; pápus de páleas livres, estreito lanceoladas, 5,5-6 mm compr.

Material selecionado: BRASIL. GOIÁS: Mossâmedes, Serra Dourada, subida para a Reserva Biológica Prof. José Angelo Rizzo, 11.X.2014, G.H. Silva et al. 174 (UFG). Distribuição, hábitat e fenologia: Tocantins, Maranhão, Goiás, Distrito Federal e Minas Gerais (BFG 2015). Em Goiás ocorre em campo sujo, 


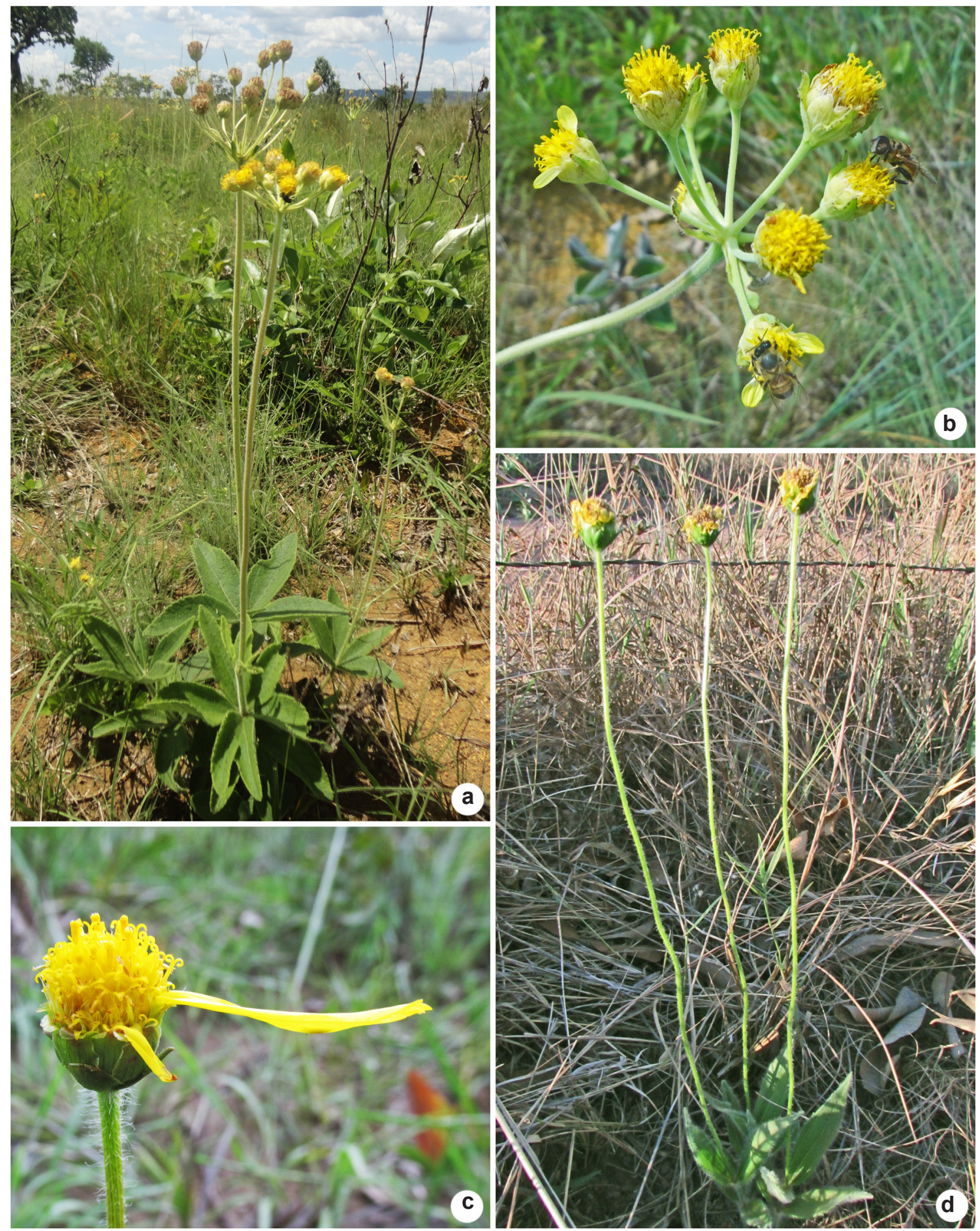

Figura 4 - a,b. Calea mediterranea - a. hábito; b. capitulescência. c,d. C. multipilinervia - c. capítulo; d. hábito. Figure 4 - a,b. Calea mediterranea - a. habit; b. capitulescence. c,d. C. multipilinervia - c. capitulum; d. habit. 

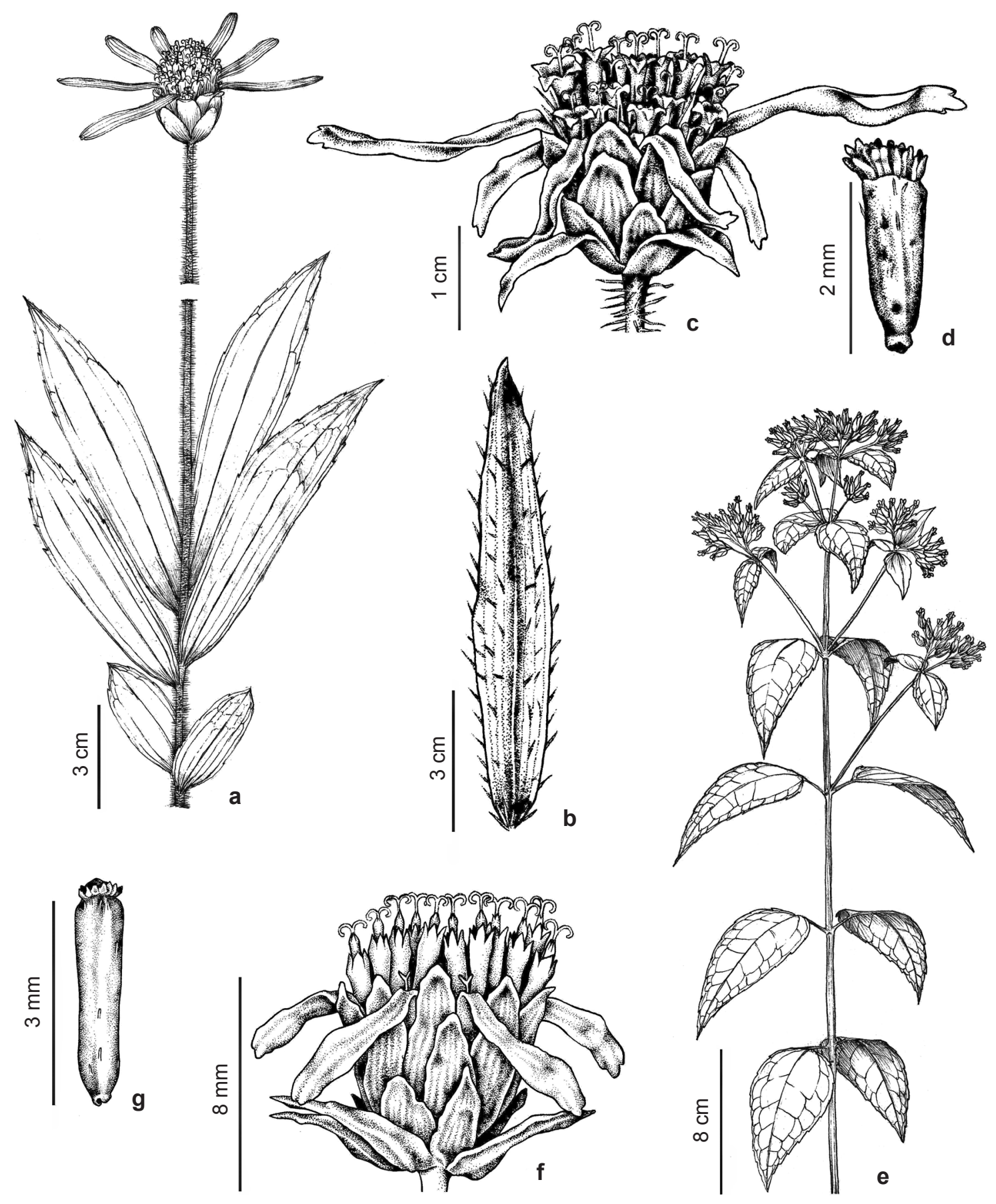

Figura 5 - a. Calea multiplinervia - hábito. b-d. C. nervosa - b. folha; c. capítulo; d. cipsela. e. C. polycephala - hábito. f,g. C. ramosissima - f. capítulo; g. cipsela. [a. desenhado de Souza \& Inocêncio 1360 (UFG); b-d. desenhados de Bringel \& Moreira 767 (UB); e. desenhado de Gardner 4246 (K); f,g. desenhados de Pacheco \& Versiane 1057 (HUFU)].

Figure 5 -a. Calea multiplinervia - habit. b-d. C. nervosa-b. leaf; c. capitulum; d. cypsela. e. C. polycephala-habit. f,g. C. ramosissima - f. capitulum; g. cypsela. [a. drawed from Souza \& Inocêncio 1360 (UFG); b-d. drawed from Bringel \& Moreira 767 (UB); e. drawed from 4246 (K); f,g. drawed from Pacheco \& Versiane 1057 (HUFU)]. 
campo limpo, campo rupestre, cerrado rupestre, entre 375 e $1.281 \mathrm{~m}$. Fértil de junho a dezembro.

Calea multiplinervia pode ser reconhecida por possuir entrenós, geralmente, curtos dando a impressão de filotaxia rosulada e por suas folhas com nervação acródroma basal com nervuras bem marcadas. Assemelha-se principalemnte a $C$. abbreviata, C. aldamoides por características já mencionadas nos comentários dessas duas espécies, onde também são citadas suas diferenças. Também é morfologicamente afim de C. cuneifolia por apresentar longos pedúnculos, capítulos radiados e solitários, multifloros e cipselas mais curtas que o pápus. Porém, diferencia-se de C. cuneifolia por características já mencionadas nos comentários desta espécie.

18. Calea nervosa G.M.Barroso, Sellowia 26: 109. 1975.

Fig. 5b-d

Arbustos eretos, $15-50 \mathrm{~cm}$ alt. Folhas opostas, pecíolos 1-4 mm compr.; lâmina lanceolada, 3,3-14 $\times 0,5-2,6 \mathrm{~cm}$, venação acródroma basal, ápice agudo, base aguda a obtusa, margem serreada, hirsuta em ambas as faces. Capitulescência dicasiforme. Capítulos radiados; pedúnculo 3,1-10,4 cm compr., hirsuto. Invólucro campanulado, dimórfico, 1,4-1,8 × 1,3-1,7 cm, 4-seriado; 1 série externa de 4-5 brácteas involucrais foliáceas, lanceoladas $1,8-5 \times 0,4-0,8 \mathrm{~cm}$, ápice agudo, margem inteira, hirsutas; 3 séries internas de brácteas involucrais escariosas, ovais, $0,8-1,6 \times 0,5-0,7 \mathrm{~cm}$, ápice obtuso a arredondado, glabras. Eixo da inflorescência convexo; páleas planas, lineares $8 \mathrm{~mm}$ compr., ápice agudo. Flores do raio 7-16, corola amarela, tubo 4,5-5,6 mm compr., lâmina 1,3-1,9 × 0,3-0,4 mm, ápice 4-lobulado; estilete 5-11 mm compr., ramos do estilete 1,1-2,6 mm compr. Flores do disco 40-80, corola amarela, $6,5-7,6 \mathrm{~mm}$ compr., tubo $2-2,4 \mathrm{~mm}$ compr., glabra, limbo 3-3,3 mm compr., lacínios 1,4-1,6 mm compr., glabra; anteras 3,3-3,5 mm compr.; estilete $8-9 \mathrm{~mm}$ compr., ramos do estilete ca. 2,2 mm compr. Cipselas 4-angulosas, 3,4-4 mm compr., subglabras a glabras; pápus de páleas livres, oblongas, 0,9-1,2 mm compr.

Material selecionado: BRASIL. GOIÁS: Alto Paraíso de Goiás, 48,5 km de Alto Paraíso de Goiás, na estrada para São João da Aliança, barranco na beira da estrada 14'33'29'S, 47 29'40'W, 30.III.2011, J. Bringel \& H.J.C. Moreira 767 (UB).

Distribuição, hábitat e fenologia: Espécie endêmica da região da Chapada dos Veadeiros nos municípios de São João da Aliança e Alto Paraíso de Goiás onde é encontrada em campo limpo e campo sujo em elevações de 950 a 1.100 m. Fértil de fevereiro a maio.

Calea nervosa é notável por suas folhas com nervação acródroma basal com várias nervuras aparentes que são comparáveis as de C. multiplinervia. No entanto, C. nervosa difere desta por apresentar capitulescências dicasiformes (vs. capítulos solitários), presença de brácteas involucrais externas foliáceas ( $v s$. ausência) e pápus 0,9-1,2 mm compr (vs. 5,5-6 mm compr.).

19. Calea polycephala (Baker) H.Rob., Phytologia 32(5): 428. 1975.

Fig. 5e

Subarbustos eretos ou escandentes, $1-1,8 \mathrm{~m}$ alt. Folhas opostas; pecíolos $0,6-1,5 \mathrm{~cm}$ compr.; lâmina oval a lanceolada, 2,9-9,3 × 1,2-3,5 cm, venação actinódroma suprabasal, ápice agudo a atenuado, base obtusa, margem serreada, puberulenta em ambas as faces. Capitulescência corimboso-dicasiforme. Capítulos discoides; pedúnculo $0,3-1,9 \mathrm{~cm}$ compr., puberulento. Invólucro cilíndrico, monomórfico, 7,5-8 × 3,5-4 $\mathrm{mm}, 4$-seriado; brácteas involucrais escariosas, ovais a oblongo-elípticas, $1,6-6,7 \times 1,7-2,8$ $\mathrm{mm}$, glabras. Eixo da inflorescência convexo; páleas planas, lineares, 5,4-5,5 mm compr., ápice agudo. Flores 5-6, corola amarela, 3,2-4,1 mm compr., tubo 1,3-1,9 mm compr., limbo 0,8-1 mm compr., lacínios 1-1,5 mm compr.; anteras 1,7-2 $\mathrm{mm}$ compr.; estilete $3-5 \mathrm{~mm}$ compr., ramos do estilete $0,7-1 \mathrm{~mm}$ compr. Cipselas subcilíndricas a 4-angulosas, 4-5 mm compr., glabras; pápus de páleas livres, ovais, 0,3-0,5 mm compr.

Material selecionado: BRASIL. GOIÁS: Pirenópolis, Serra dos Pireneus, caminho para a cacheira dos Dragões/ Rosários, $c a .11 \mathrm{~km}$, da cachoeira dos Dragões, $791 \mathrm{~m}$, 1542'31.794”'S, 4901'06.181'W, 26.II.2015, G.H. Silva et al. 219 (UFG).

Distribuição, hábitat e fenologia: Pará, Tocantins, Maranhão, Mato Grosso, Goiás, Minas Gerais e São Paulo (BFG 2015). No estado de Goiás cresce em floresta de galeria e floresta semidecídua entre elevações de 600 a $791 \mathrm{~m}$. Encontrada fértil de janeiro a março, em maio e em agosto.

Esta espécie é morfologicamente próxima de Calea diffusa e C. robinsoniana pelo fato de as três apresentarem capítulos discoides com menos de 30 flores e pápus menor que $2 \mathrm{~mm}$ compr. Porém, $C$. polycephala difere de $C$. diffusa e $C$. robinsoniana por apresentar pecíolos relativamente longos (0,6-1,5 cm compr.), enquanto $C$. diffusa apresenta pecíolos curtos (1-3 mm compr.) e $C$. 
robinsoniana folhas sésseis. Também difere de $C$. robinsoniana por possuir pedúnculo com 0,3-1,9 cm compr. (vs. 2,7-10,6 cm compr.) e invólucro 4-seriado (vs. 3-seriado). Outras diferenças entre $C$. polycephala e $C$. diffusa são mencionadas nos comentários dessa última.

\section{Calea quadrifolia Pruski \& Urbatsch, Brittonia} 40(4): 341. 1988. Fig. 6a,b

Subarbustos eretos, 0,4-0,7(-2) $\mathrm{m}$ alt. Folhas verticiladas, sésseis; lâmina oval a elíptica, 1,5-3,5 $\times$ 0,7-6,9 cm, venação broquidódroma, ápice agudo, base aguda a obtusa, margem serreada, glabra a escabra em ambas as faces. Capitulescência umbeliforme. Capítulos radiados; pedúnculos 0,6$14,4 \mathrm{~cm}$ compr., glabros a pubescentes. Invólucro campanulado, dimórfico, 1,2-1,7 × 0,9-1,3 cm; 5-seriado; 1-2 séries externas de 5-8 brácteas involucrais foliáceas, lanceoladas, 0,6-1,4 × 0,3-0,6 $\mathrm{mm}$, ápice agudo, margem serreada, escabras; 3-4 séries internas de brácteas involucrais escariosas, oblongas, 0,6-1,9 × 0,3-0,5 mm, ápice agudo a obtuso, glabras. Eixo da inflorescência convexo, paleáceo; páleas conduplicadas, lineares, 0,7-1,5 cm compr., ápice agudo. Flores do raio 8-14, corola amarela, tubo 3,8-5 mm compr., lâmina 13-18 × 4-5 $\mathrm{mm}$, ápice 3-lobulado; estilete 6-7,2 $\mathrm{mm}$ compr., ramos do estilete 1,4-1,8 $\mathrm{mm}$ compr. Flores do disco 45-60, corola amarela, 5,6-8 mm compr., tubo 1,3-2,5 mm compr., glabra, limbo 3-4 mm compr., lacínios 1,2-2,4 mm compr.; anteras 2,8-3,8 mm compr.; estilete 6,4-7,7 mm compr., ramos do estilete 1,3-2,2 mm compr. Cipselas, 4-angulosas, 3,5-5 mm compr., glabrescentes, tricomas apenas nos ângulos; pápus de páleas livres, oblongas, 1,6-2,7 mm compr.

Material selecionado: BRASIL. GOIÁS: Pirenópolis, Parque Estadual dos Pireneus, estrada ao lado direito da entrada do Parque ca. 15 min. de caminhada, após uma trifurcação, caminho da direita, $1287 \mathrm{~m}, 15^{\circ} 48^{\prime} 31,194$ 'S, 4852'48.997'W, 9.IV.2015, G.H. Silva \& R.C. Teixeira 309 (UFG).

Distribuição, hábitat e fenologia: Goiás, Distrito Federal e Minas Gerais (BFG 2015). No estado de Goiás cresce em campo rupestre, campo limpo, campo sujo, cerrado rupestre e cerrado s.s. entre 925 e $1.380 \mathrm{~m}$. Flores e frutos de janeiro a julho.

Calea quadrifolia pode ser confundida com $C$. reticulata, $C$. mediterranea e $C$. chapadensis por caracteres já citados nos comentários de $C$. mediterranea. Contudo, C. quadrifolia distinguese das três referidas espécies por não apresentar a capitulescência umbeliforme elevada por um escapo, pois nesta espécie a capitulescência cresce a partir dos últimos nós no ápice dos ramos. Calea quadrifolia se diferencia ainda de $C$. reticulata e $C$. chapadensis por passuir capítulos radiados (vs. discoides). Além disso, C. quadrifolia possui pápus com 1,6-2,7 $\mathrm{mm}$ compr. diferindo das outras aqui comentadas que apresentam pápus com 4,4-6,7 mm compr.

21. Calea ramosissima Baker, Fl. bras. 6(3): 257. 1884.

Fig. 5f,g

Subarbustos eretos, 0,3-1,5 $\mathrm{m}$ alt. Folhas opostas; sésseis; lâmina linear, 1-5 × 0,1-0,2 $\mathrm{cm}$, venação camptódroma, ápice agudo, base aguda, margem inteira, estrigosa em ambas as faces. Capitulescências corimboso-dicasiformes. Capítulos radiados; pedúnculos 0,7-2,5 cm compr., estrigosos. Invólucro campanulado, dimórfico, 6-8 × 3-7 mm, 4-5-seriado; 1 série externa de 4-5 brácteas involucrais foliáceas, lineares, 3-9 $\times$ 1-2 mm, ápice agudo, margem inteira; 3-4 séries internas de brácteas involucrais escariosas, deltoides a oblongas, 3-8 × 2-4 mm, ápice agudo a obtuso, glabras. Eixo da inflorescência convexo; páleas conduplicadas, oblongas, 3-7 mm compr. Flores do raio 4-7, tubo da corola $2-2,5 \mathrm{~mm}$ compr., lâmina 5-7 × 2-3 mm, ápice 3-lobulado; estilete 5-6 mm compr., ramos do estilete 0,3-0,5 mm compr. Flores do disco 9-20, corola amarela, 4-5 mm compr., tubo 1-2 mm compr., limbo 0,8-1 mm compr., lacínios 2-2,2 mm compr., glabra; anteras 2-2,5 mm compr.; estilete 4,5-6 $\mathrm{mm}$ compr., ramos do estilete $0,6-0,8 \mathrm{~mm}$ compr. Cipselas, 4-angulosas, 2,6-3,2 mm compr., glabras; pápus de páleas livres, ovais, 0,2-0,3 mm compr.

Material selecionado: BRASIL. GOIÁS: Alto Paraíso de Goiás, GO-239 km 11, aproximadamente $2 \mathrm{~km}$ da entrada para o Rio dos Couros, $14^{\circ} 10^{\prime} 02$ 'S, 47³7'55,5'W, 6.IX.2014, A.O. Souza et al. 1314 (UFG).

Distribuição, hábitat e fenologia: Goiás e Minas Gerais (BFG 2015). No estado de Goiás ocorre em campo limpo, campo rupestre, cerrado rupestre entre elevações de 914 a 1.180 m. Fértil nos meses de janeiro a setembro.

Calea ramosissima possui afinidades morfológicas com C. gardneriana e C. hymenolepis, porém se diferencia da primeira principalmente por apresentar brácteas involucrais externas foliáceas ( $v s$. brácteas involucrais externas escariosas) e lâmina foliar estrigosa ( $v s$. escabra). As características 

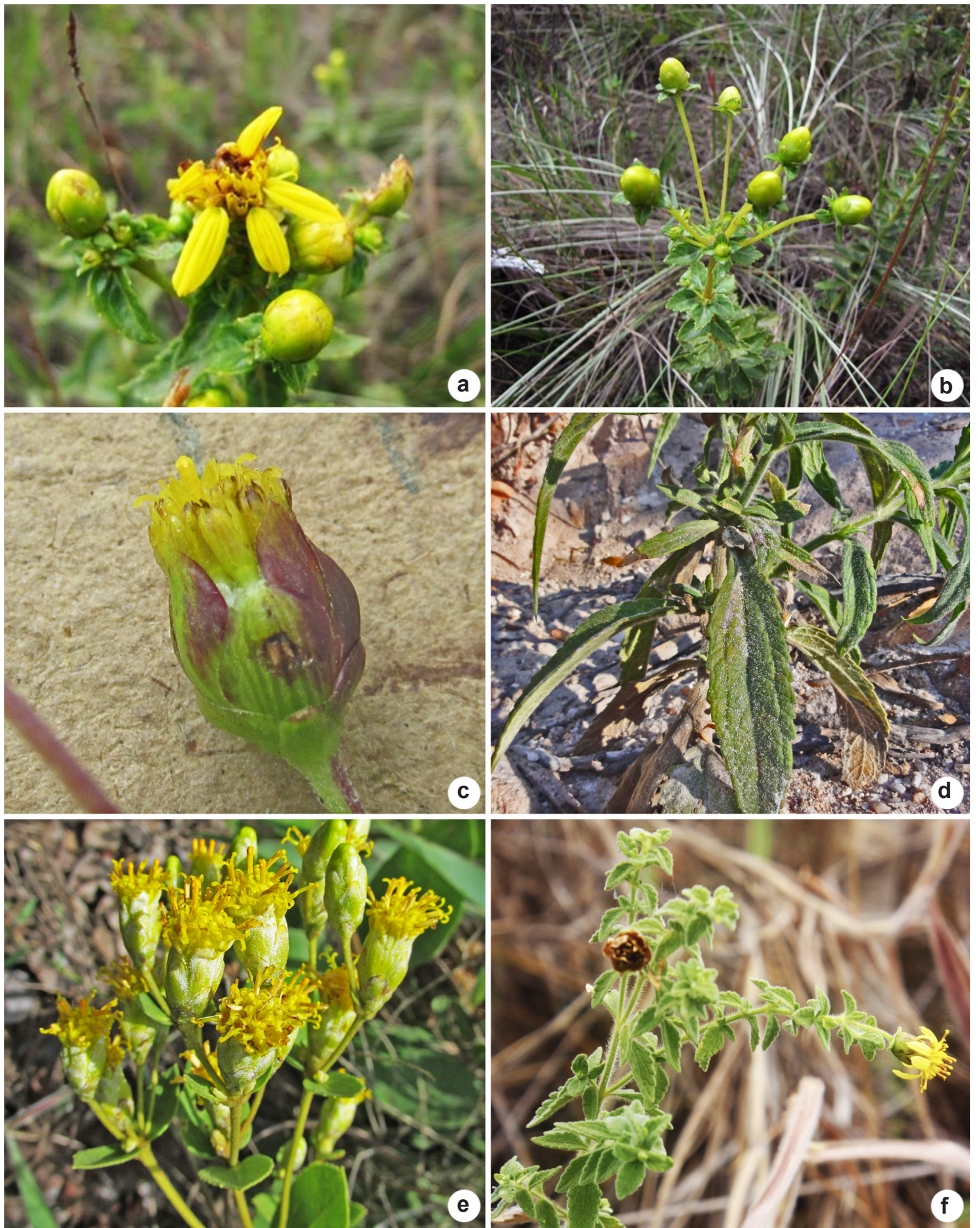

Figura 6 - a,b. Calea quadrifolia - a. capítulos; b. capitulescência. c,d. C. robinsoniana - c. capítulo; d. folhas. e. C. sickii - capitulescência. f. C. teucriifolia - capitulescência.

Figure 6-a,b. Calea quadrifolia - a. capitula; b. capitulescence. c,d. C. robinsoniana -c. capitulum; d. leaves. e. C. sickii - capitulescence. f. C. teucriifolia - capitulescence. 
que distinguem C. ramosissima de C. hymenolepis são mencionadas nos comentários de $C$. hymenolepis.

22. Calea reticulata Gardner, London J. Bot. 7: 416. 1848.

Ervas eretas, 30-65 cm alt. Folhas verticiladas; sésseis; lâmina elíptica a lanceolada, 2-7,8 $\times$ 0,5-2,5 cm, venação camptódroma, ápice agudo, base aguda, margem serreada, escabra em ambas as faces. Capítulescências umbeliformes. Capítulos discoides; pedúnculos 1,5-7 cm compr., velutinos. Invólucro campanulado, 0,8-1 × 1-1,3 cm, 2-seriado, 1 série externa de 3-5 brácteas involucrais foliáceas, oblongas, $1-1,4 \times 0,3-0,5 \mathrm{~cm}$, ápice agudo, margem serreada, pubescentes; 1 série interna, brácteas involucrais escariosas, oblongas, $0,8-1,1 \times 0,2-0,4$ $\mathrm{cm}$, ápice agudo, pubescentes. Eixo da inflorescência convexo; páleas conduplicadas, obovais, ca. 6 mm compr. Flores 15-39, corola 5-6 mm compr., tubo 1,8-2 mm compr., glabra, limbo 1,2-2,3 mm compr., lacínios 1,5-2 mm compr.; anteras 2-3 mm compr.; estilete 4,5-6 mm compr., ramos do estilete 1-1,3 mm compr. Cipselas obpiramidais, ca. $3 \mathrm{~mm}$ compr., pubescentes; pápus de páleas livres, linearlanceoladas, ca. $5 \mathrm{~mm}$ compr.

Material selecionado: BRASIL. GOIÁS: São Domingos, Estrada de terra de São Domingos a Guarani de Goiás, 720 m, 1322'53''S, 46¹8'17''W, 14.XI.2011, J. Bringel, J.E.Q. Faria Jr. \& H.J.C. Moreira 896 (UB).

Distribuição, hábitat e fenologia: Tocantins e Goiás (BFG 2015). Ocorre em cerrado rupestre, entre elevações de 320 e $720 \mathrm{~m}$. Flores e frutos de outubro a novembro.

Calea reticulata assemelha-se a C. chapadensis, C. mediterranea e C. quadrifolia. Porém, distingue-se das duas últimas por possuir capítulos discoides ( $v S$. radiados) e de $C$. quadrifolia por apresentar cipselas pubescentes e pápus de páleas linear-lanceoladas com ca. $5 \mathrm{~cm}$ compr. (vs. glabrescente, com tricomas apenas nos ângulos e pápus de páleas oblongas com 1,6-2,7 mm compr.). As diferenças entre $C$. reticulata e $C$. chapadensis já foram mencionadas nos comentários desta última.

23. Calea robinsoniana Pruski, Kew Bull. 53(3): 688. 1998.

Figs. 6c,d; 7a-c

Subarbustos a arbustos eretos, 0,7-2 $\mathrm{m}$ alt. Folhas opostas; sésseis; lâmina linear a lanceolada, 2,7-18 × 0,4-4,6 cm, venação broquidódroma, ápice agudo, base aguda, margem serreada, pubescente a tomentosa em ambas as faces. Capitulescência corimboso-dicasiforme. Capítulos discoides; pedúnculos 2,7-10,6 cm compr., pubescentes. Invólucro campanulado, 6-7 × 5-6,7 mm, 3-seriado;
1 série externa de 2 brácteas involucrais foliáceas, lanceoladas, 2,7-6 × 1,7-2,3 mm, ápice agudo, margem inteira, glabras; 2 séries internas de brácteas involucrais escariosas, orbiculares a obovais 3-6× 2,7-3,5 mm, ápice obtuso a arredondado, glabras, manchas vináceas. Eixo da inflorescência convexo, epaleáceo. Flores 11-26, corola amarela, 3-4,4 mm compr., tubo 1-1,8 mm compr., limbo 1-1,8 mm compr., lacínios 0,6-1,2 mm compr., glabra; anteras 1,5-2 mm compr.; estilete 3-4 mm compr., ramos do estilete $0,5-0,9 \mathrm{~mm}$ compr. Cipselas 4-angulosas, 2,8-3 × 0,9-1,3 mm, subglabras a glabras; pápus de páleas livres, obovais a oblanceoladas, 0,8-1,9 mm compr.

Material selecionado: BRASIL. GOIÁS, Baliza: chácara Vale da Neblina, trilha para o rio, cerrado típico, 16³1'14.887'S, 52³6'24.921”W, 392 m, 26.XII.2014, G.H. Silva 208 (UFG).

Distribuição, hábitat e fenologia: Mato Grosso e Goiás. Ocorre em cerrado típico em áreas próximas a cursos de água, no estado de Goiás entre 163 e 394 m. Planta rara com poucos exemplares coletados na região da bacia do Araguaia. Fértil nos meses de fevereiro, junho e dezembro.

Calea robinsoniana relaciona-se morfologicamente à $C$. diffusa pelo fato de ambas apresentarem capítulos discoides e capitulescência dicásio-umbeliformes difusas, além disso, na maturidade o invólucro de $C$. robinsoniana torna-se escurecido como o de $C$. diffusa. As espécies podem ser diferenciadas pelo tamanho de suas folhas (1-3,5 $\times 0,3-1,3 \mathrm{~cm}$ em $C$. diffusa vs. 2,7-18 × 0,4-4,6 $\mathrm{cm})$. Além disso, C. diffusa possui folhas pecioladas (vs. sésseis) e eixo da inflorescência paleáceo ( $v s$. epaleáceo).

24. Calea sickii (G.M.Barroso) Urbatsch, Zlotsky \& Pruski, Syst. Bot. 11(4): 504. 1986.

Figs. 6e,f; 7d

Subarbustos a arbustos eretos, 0,8-1,5 m alt. Folhas opostas; pecíolos 1-3 mm; lâmina elíptica, oval ou orbicular, 1,3-10,5 × 1-9 cm, venação actinódroma suprabasal, base subcordada a arredondada, margem serreada a denteada, escabra em ambas as faces. Capitulescência corimbosodicasiforme. Capítulos discoides; pedúnculos até 2,4 cm compr., escabros. Invólucro obcônico, 1,4-1,8 $\times$ 0,5-0,8 cm, 5-6-seriado; brácteas involucrais escariosas, oblongas, 0,4-1,3 × 0,2-0,4 mm, ápice obtuso a arredondado, glabras, ápice flocoso. Eixo da inflorescência convexo, páleas conduplicadas, oblanceoladas, ca. 1,2 cm compr., ápice obtuso. Flores 12-22, corola 7-8,5 mm compr., tubo 3,2-3,4 mm compr., glanduloso, limbo 2,3-3,3 mm compr., 

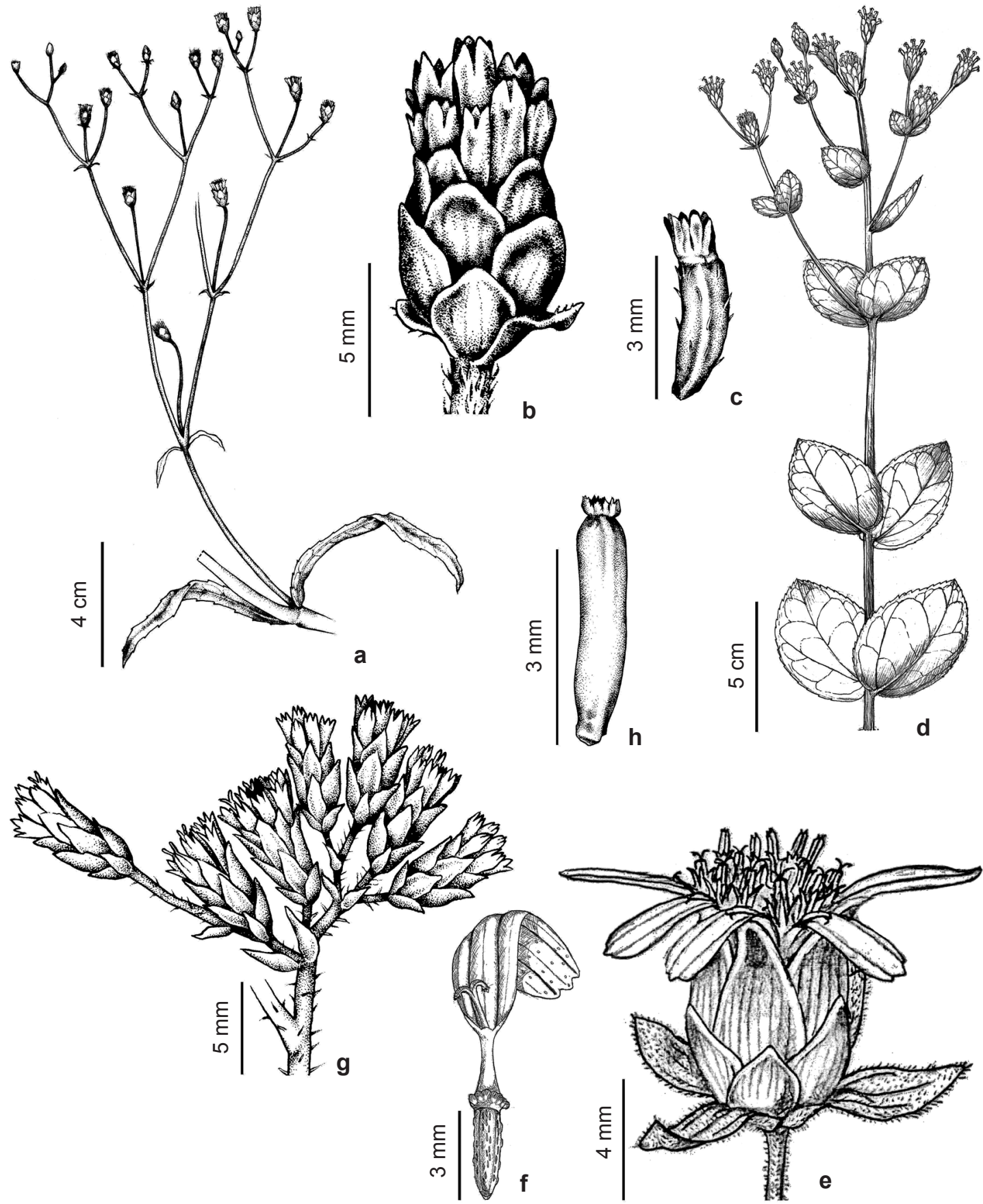

Figura 7 - a-c. Calea robinsoniana - a. capitulescência; b. capítulo; c. cipsela. d. C. sickii - hábito. e,f. Grupo $C$. teucriifolia - e. capítulo; f. flor do raio. g,h. C. tocantina - g. porção da capitulescência; h. cipsela. [a-c. desenhado de Silva 208 (UFG); d. desenhado de Pacheco \& Versiane 1055 (HUFU); e,f. desenhados de Coimbra, Paschoal \& Yang 391 (UFG); g,h. desenhados de Cordeiro et al. 5009 (MBM)].

Figure 7 - a-c. Calea robinsoniana - a. capitulescence; b. capitulum; c. cypsela. d. C. sickii - habit. e,f. Group C. teucriifolia - e. capitulum; f. ray floret. g-h. C. tocantina - g. capitulescence; h. cypsela. [a-c. drawed from Silva 208 (UFG); d. drawed from Pacheco \& Versiane 1055 (HUFU); e,f. drawed from Coimbra, Paschoal \& Yang 391 (UFG); g,h. drawed from Cordeiro et al. 5009 (MBM)]. 
glanduloso, lacínios 1,5-2,5 mm compr.; anteras ca. 3,5 mm compr.; estilete 9-11 mm compr., ramos do estilete 1,5-2 mm compr. Cipselas 4-angulosas, 5-6 mm compr., velutinas; pápus coroniforme, 3-5 mm compr.

Material selecionado: BRASIL. GOIÁS: Pirenópolis, Parque Estadual dos Pireneus, arredores da segunda guarita, próximo a um riacho, 23.IV.2015, G.H. Silva et al. 319 (UFG).

Distribuição, hábitat e fenologia: Goiás e Distrito Federal. Em Goiás ocorre em cerrado rupestre, campo limpo e campo rupestre de 1.000 e $1.300 \mathrm{~m}$. Flores e frutos de janeiro a outubro.

Calea sickii tem como espécies morfologicamente afins $C$. fruticosa e $C$. irwinii e suas semelhanças e diferenças constam nos comentários destas duas últimas.

\section{Grupo Calea teucriifolia (Gardner) Baker, (sensu} Pruski \& Urbatsch 1987). Figs. 6f; 7e,f

Subarbustos eretos, 0,3-1,5 $\mathrm{m}$ alt. Folhas opostas; pecíolos até $3 \mathrm{~mm}$ compr.; lâmina oval, oblanceolada ou rômbica, 0,7-4,5 × 0,3-2,2 cm, venação camptódroma, ápice agudo, base aguda, margem serreada, pubescente a tomentosa em ambas as faces. Capitulescência corimboso-dicasiforme. Capítulos radiados; pedúnculos 0,8-3 cm compr., pubescentes a tomentosos. Invólucro campanulado, 0,7-1 × 0,6-0,9 cm, 3-4-seriado; 1-2 séries externas de $4-6$ brácteas involucrais foliáceas, ovais, oblongas ou elípticas, $0,4-1,1 \times 2-0,4 \mathrm{~cm}$, ápice agudo, margem inteira a serreada, pubescente a tomentosa; 2-3 séries internas de brácteas involucrais escariosas, ovais a oblongas, 4-8 × 3,5-5 mm, ápice agudo, glabras. Eixo da inflorescência convexo; páleas conduplicadas, oblongas, 4-5 mm compr. Flores do raio 4-9, tubo da corola 2-3,5 mm compr., lâmina 6-9 × 1,5-3 mm, ápice 3-lobulado; estilete 4-5 mm compr., ramos do estilete $0,3-0,5 \mathrm{~mm}$ compr. Flores do disco 12-35, corola 4-6 mm compr., glabras, tubo 1,5-2,3 mm compr., limbo 0,6-1,2 mm compr., lacínios 1,9-2,5 mm compr.; anteras 2-3 mm compr.; estilete 5-6 mm compr., ramos do estilete $0,8-1 \mathrm{~mm}$ compr. Cipselas, 4-angulosas, 2,4-3,5 mm compr., glabras; pápus de páleas livres, ovais a oblongas, 0,3-2 mm compr.

Material selecionado: BRASIL. GOIÁS: Cristalina, saída de Cristalina, sentido Luziania, próximo a casa abandonada, ca. $5 \mathrm{~km}$ após a Loja Mundial Gemas e Pedras Preciosas, $1.170 \mathrm{~m}, 16^{\circ} 43^{\prime} 12.8^{\prime} \mathrm{S}, 47^{\circ} 39^{\prime} 7.4^{\prime \prime} \mathrm{W}$, 8.IX.2014, A.O. Sousa \& L.S. Inocêncio 1331, 1332 (UFG). Posse, Cerrado na entrada da cidade $c a .2 \mathrm{~km}$ do Cristo em direção à cidade, $835 \mathrm{~m}, 14^{\circ} 43^{\prime} 12.8^{\prime \prime} \mathrm{S}, 47^{\circ} 39^{\prime} 7.4$ ”'W, 2.III.2015,
A.O. Sousa, C.C. Oliveira \& L.S. Inocêncio 1669 (UFG). Distribuição, hábitat e fenologia: Maranhão, Bahia, Mato Grosso, Goiás, Distrito Federal, Mato Grosso do Sul e Minas Gerais (BFG 2015). No estado de Goiás ocorre em campo sujo, campo limpo, campo rupestre, cerrado s.s. e borda de floresta entre 738 e $1.391 \mathrm{~m}$. Encontrada fértil durante todo o ano.

O grupo Calea teucriifolia foi descrito por Pruski \& Urbatsch (1987) para agrupar quatro espécies (C. teucriifolia, C. ferruginea, C. microphylla e $C$. villosa) de difícil delimitação. Assim como Pruski \& Urbatsch (1987), acreditamos que, estudos futuros com um extensivo trabalho de campo certamente levarão a sinonimização desses quatro nomes. Este grupo tem como espécies morfologicamente afins C. hypericiifolia e C. ramosissima por apresentarem folhas relativamente pequenas, capítulos com tamanhos próximos, invólucro externo foliáceo e cipselas mais longas que o pápus. As espécies do grupo C. teucriifolia diferem de $C$. ramosissima por possuir folhas com lâmina oval, oblanceolada ou ainda rômbica ( $v s$. linear) com margem serreada (vs. inteira) e pubescentes a tomentosas (vs. estrigosas). As diferenças entre o grupo C. teucriifolia e C. hypericiifolia estão apresentadas nos comentários desta última.

26. Calea tocantina Pruski, Phytoneuron 72: 8 . 2013.

Fig. $7 \mathrm{~g}, \mathrm{~h}$

Subarbustos eretos, ca. $90 \mathrm{~cm}$ alt. Folhas opostas; pecíolo 2-4 mm compr.; lâmina elíptica a estreito elíptica, 2,8-7,7×0,4-2 cm, venação broquidódroma, ápice agudo, base aguda, margem serreada, face adaxial hirsuta, abaxial lanuginosa. Capitulescência corimboso-dicasiforme. Capítulos discoides; pedúnculos 3-7 mm compr., puberulentos. Invólucro campanulado, 7-8 × 4-5 mm, 3-seriado; brácteas involucrais escariosas, lanceoladas, 3-6,6 $\times 1,7-2 \mathrm{~mm}$, ápice agudo, glabras, vináceas. Eixo da inflorescência convexo; páleas conduplicadas, oblongas, 5-6 mm compr., ápice acuminado. Flores $10-12$, corola $c a .4 \mathrm{~mm}$ compr., glabra, tubo $1-1,3$ mm compr., limbo ca. 1,1 mm compr., lacínios $c a$. 1,5 mm compr.; anteras $c a$. $2 \mathrm{~mm}$ compr.; estilete $c a$. 3,5 mm compr., ramos do estilete $c a .1 \mathrm{~mm}$ compr. Cipselas 4-angulosas, 3,3-3,5 mm compr., glabras; pápus de páleas livres, ovais, $c a$. $0,3 \mathrm{~mm}$ compr. Material examinado: BRASIL. GOIÁS: São Domingos, base do Morro Pé-de-Moleque, $738 \mathrm{~m}, 13^{\circ} 21^{\prime} 05^{\prime} \mathrm{S}$, 4618'36'W, 22.IV.2013, J. Cordeiro et al. 5009 (MBM). Material adicional examinado: BRASIL. TOCANTINS. Arraias, Rod. TO-050, km 415, 6 km O de Arraias, 520 m, 10.V.2000, G. Hatschbach, A. Schinini \& E. Barbosa 70858 (Isótipo MBM). 
Distribuição, hábitat e fenologia: Tocantins e Goiás onde cresce em campo sujo a ca. $738 \mathrm{~m}$. Trata-se de uma espécie rara conhecida por apenas três registros. Coletada com flores e frutos em abril.

Calea tocantina é morfologicamente próxima de $C$. diffusa e $C$. robinsoniana por apresentar capítulescência corimboso-dicasiforme, pequenos capítulos $(6-8 \times 4-6,7 \mathrm{~mm})$ discoides, invólucro 3 -seriado com brácteas involucrais vináceas ou com máculas vináceas, além de pápus menor que $2 \mathrm{~mm}$ compr. Calea tocantina, contudo, difere de C. diffusa por possuir lâmina foliar com face abaxial lanuginosa e adaxial hirsuta (vs. escabra), invólucro campanulado (vs. cilíndrico), brácteas involucrais lanceoladas (vs. ovais a elípticas) e páleas conduplicadas e oblongas (vs. planas e lineares). Diferencia-se de C. robinsoniana por apresentar pedúnculos com 3-7 mm compr. (vs. 2,7-10,6 cm compr.), brácteas involucrais externas escariosas ( $v s$. foliáceas) e eixo da inflorescência paleáceo ( $v S$. epaleáceo) e corolas com lóbulos purpúreos (vs. amarelos).

27. Calea verticillata (Klatt) Pruski, Kew Bull. 53(3): 689. 1998.

Iconografia: Pruski (1998: 690, Fig. 2)

Subarbustos eretos, $50-80 \mathrm{~cm}$ alt. Folhas opostas, sésseis; lâmina oval, 1,7-4,8 × 1,3-3,3 cm, venação acródroma basal, ápice agudo a obtuso, base obtusa a cordada, margem serreada, velutina a escabra em ambas as faces. Capitulescência dicasiforme. Capítulos radiados; pedúnculos 7,4-17 cm compr., tomentosos. Invólucro campanulado, 1,6-1,9 $\times$ 1,5-2,4 cm, 4-seriado; 1 série externa de 2-4 brácteas involucrais foliáceas, ovais a orbiculares, 4,2-9,6 × 4,2$8,8 \mathrm{~mm}$, ápice obtuso a arredondado, margem inteira, velutinas; 3 séries internas de brácteas involucrais escariosas, oblongas, 0,6-2 ×0,4-0,8 cm, ápice agudo a arredondado, glabras. Eixo da inflorescência cônico; páleas planas, lineares, 1,4-2 cm compr., ápice agudo. Flores do raio 9-14, tubo da corola 6-7,5 mm compr., lâmina 1,4-2,5 ×0,4-1,1 mm, ápice 4-lobulado; estilete 8-11 mm compr., ramos do estilete 1,8-2,2 mm compr. Flores do disco 40-81, corola 9-11 mm compr., tubo 4,5-5 mm compr., glabra, limbo 3-3,5 mm compr., lacínios 1,5-2,5 mm compr.; anteras 3-3,5 mm compr.; estilete 10-12 mm compr., ramos do estilete 1,8-2,3 mm compr. Cipselas obovoides, 4-angulosas, 3-4 mm compr., seríceas; pápus de páleas livres, lanceoladas, 9-12 mm compr.

Material adicional selecionado: BRASIL. MATO GROSSO DO SUL: Iguatemi, Rod. MS-295, próximo ao km 35, 10.III.2004, G. Hatschbach, M. Hatschbach \& E. Barbosa 76880 (MBM).
Distribuição, hábitat e fenologia: Goiás, Mato Grosso do Sul, Paraná e São Paulo (Pruski 1998). Para o estado de Goiás é conhecida apenas pelo síntipo de Calea catalaonensis Krasch. (sinônimo de $C$. verticillata), coletado em Catalão em 1834 por Riedel (Pruski 1998). Porém, para descrição da espécie foram utilizados espécimes provenientes do estado de Mato Grosso do Sul. Isso foi necessário, pois não foi possível consultar o material-tipo e não há coletas recentes da espécie para o estado de Goiás. Fértil de janeiro a abril.

Pode ser reconhecida por apresentar capitulescências dicasiformes com capítulos grandes (1,6-1,9 × 1,5-2,4 cm) e radiados, páleas do eixo da inflorescência lineares e planas e por apresentar páleas do pápus linear-lanceoladas mais longas que a cipsela. É morfologicamente próxima à $C$. cuneifolia da qual se diferencia por apresentar hábito subarbustivo ramificado e capítulescências dicasiformes ( $v s$. subarbustos simples e capítulos solitários) e pelo eixo da inflorescência cônico (vs. convexo).

\section{Agradecimentos}

Os autores agradecem aos curadores dos herbários visitados a hospitalidade e o envio de doações e empréstimos, e à UFG a disponibilização dos carros oficiais para as viagens. O primeiro autor agradece ainda à CAPES a bolsa de mestrado concedida. Os autores também são gratos pelas valiosas contribuições dos dois revisores anônimos.

\section{Referências}

Alvares CA, Stape JL, Sentelhas PC, Gonçalves JLM \& Sparovek G (2014) Köppen's climate classification map for Brazil. Meteorologische Zeitschrift 22: 711-728.

Ash A, Ellis B, Hickey LJ, Jonhson K, Wilf P \& Wing S (1999) Maual of leaf arquitecture: morphological description and categorization of dicotyledonous and net-veined monocotyledonous Angiosperms. Smithsonian Institution, Washington. 67p.

Baker JG (1884) Compositae: Helianthoideae. In: Martius CFP \& Eichler AW (eds.) Flora brasiliensis. Lipsiae, Munchen. Vol. 6. Pp. 251-268.

Baldwin BG (2009) The Heliantheae Alliance In: Funk VA, Susanna A, Stuessy TF \& Bayer RJ (eds.) Systematics, evolution, and biogeography of the Compositae. IAPT, Vienna. Pp. 689-711.

Barroso GM (1975) De Compositarum novitatibus. Sellowia 26: 102-118.

BFG - The Brazil Flora Group (2015) Growing knowledge: an overview of seed plant diversity in Brazil. Rodriguésia 66: 1085-1113. 
BPH Online - Botanico-Periodicum-Huntianum (2017) Hunt Institute for Botanical Documentation. Disponível em <http:/huntbotanical.org/databases/ show.php?1>. Acesso em 10 janeiro 2017.

Bremer K (1994) Asteraceae: cladistics \& classification. Timber Press, Portland. 752p.

Funk VA, Susanna A, Stuessy TF \& Robinson H (2009) Classification of Compositae In: Funk VA, SusannaA, Stuessy TF \& Bayer RJ (eds.) Systematics, evolution, and biogeography of the Compositae. IAPT, Vienna. Pp. 171-176.

Gonçalves EG \& Lorenzi H (2011) Morfologia vegetal: organografia e dicionário ilustrado de morfologia das plantas vasculares. $2^{\mathrm{a}}$ ed. Instituto Plantarum, São Paulo. 544p.

IBGE - Instituto Brasileiro de Geografia e Estatística (2014) PINAD - Pesquisa Nacional por Amostra de Domicílios Contínua. Dispnível em $<\mathrm{http}$ :// http:// www.ibge.gov.br/estadosat/perfil.php?sigla $=$ got $>$. Acesso em 20 fevereiro 2017.

IPNI - The International Plant Name Index (2017) The International Plant Name Index. Disponível em $<$ http://www.ipni.org/index.html $>$. Acesso em 12 janeiro 2017.

Nakajima JN, Dematteis M, Loeuille B, Teles AM, Heiden G, Schneider A, Ritter MR, Oliveira CT, Hattori EKO, Roque N, Ferreira SC, Magenta MAG, Bringel JBA, Esteves R, Almeida G, Saavedra MM, Monge M, Soares PN, Sancho G, Mondin CA, Fernandes AC, Pereira ACM, Kutschenko DC, Santos Filho LAF, Prieto PV, Borges RAX, Penedo TSA, Messina T, Liro RM, Moraes MMV, Moraes MA \& Coelho MAN (2013) Asteraceae In: Martinelli G \& Moraes MA (eds.) Livro vermelho da flora do Brasil. CNC Flora, Rio de Janeiro. Pp. 203-286.

Nakajima JN, Moraes L, Fernandes E \& Serrano T (2014) Asteraceae In: Martinelli G, Messina T \& Santos Filho L (eds.) Livro vermelho da flora do Brasil: plantas raras do Cerrado. Instituto de Pesquisas Jardim Botânico do Rio de Janeiro,Rio de Janeiro. Pp. 68-76.

Panero JL (2007a) Key to the tribes of the Heliantheae alliance In: Kadereit JW \& Jeffrey C (eds.) The families and genera of vascular plants. Vol. 8 . Flowering plants. Eudicots. Asterales. Springer, Berlin. Pp. 391-395.

Panero JL (2007b) Neurolaeneae In: Kadereit JW \& Jeffrey $\mathrm{C}$ (eds.) The families and genera of vascular plants.
Vol. 8. Flowering plants. Eudicots. Asterales. Springer, Berlin. Pp. 417-420.

Panero JL, Freire SE, Espinar LA, Crozier BS, Barboza GE \& Cantero JJ (2014) Resolution of deep nodesyelds an improved backbone phylogeny and a new basal lineage to study early evolution of Asteraceae. Molecular Phylogenetics and Evolution 80: 43-53.

Pruski JF (1998) Novelties in Calea (Compositae: Heliantheae) from South America. Kew Bulletin 53: 683-693.

Pruski JF (2005) Studies of Neotropical Compositae-I, Novelties in Calea, Clibadium, Conyza, Llerasia and Pluchea. Sida: Contributions to Botany 21:2023-2037.

Pruski JF \& Urbatsch LE (1987) Calea dalyi (Compositae: Heliantheae), a new species from the Serrania de Santiago, Bolivia. Brittonia 39: 201-204.

Pruski JF \& Urbatsch LE (1988) Five new species of Calea (Compositae: Heliantheae) from Planaltine Brazil. Brittonia 40: 341-356.

Robinson H(1975) Studies in the Heliantheae (Asteraceae). VI. Additions to the genus Calea. Phytologia 32: 426-431.

Robinson H(1979) Studies in the Heliantheae (Asteraceae). XIX. Four new species of Calea from Brazil. Phytologia 44: 270-279.

Roque N \& Bautista H (2008) Asteraceae: caracterização e morfologia floral. Ed. Universidade Federal da Bahia, Salvador. 71p.

Roque N \& Carvalho VC (2011) Estudos taxonômicos do gênero Calea (Asteraceae, Neurolaeneae) no estado da Bahia, Brasil. Rodriguésia 62: 547-561.

Silva GHL, Teles AM \& Bringel Junior JBA (2016) A new species of Calea (Asteraceae-Neurolaeneae) from Goiás State, Brazil. Phytotaxa 265: 279-284.

Silva GHL \& Teles AM (2017) Ten years later: a new species of Aspilia (Asteraceae-Heliantheae) from Chapada dos Veadeiros, Goiás, Brazil. Phytotaxa 314: 117-122.

Thiers B [continuously updated] Index herbariorum: a global directory of public herbaria and associated staff. New York Botanical Garden's Virtual Herbarium. Disponível em <http://sweetgum.nybg.org/ih/>. Acesso em 10 janeiro 2017.

Urbatsch LE, Zlotscky A \& Pruski JF (1986) Revision of Calea sect. Lemmantium (Asteraceae: Heliantheae) from Brazil. Systematic Botany 11: 501. 